\title{
İngiltere, Japonya, Norveç, Finlandiya, Singapur, Rusya ve Türk Eğitim Sistemlerinin Karşılaştırmalı Olarak İncelenmesi
}

\author{
Mehmet Arif ÖZERBAȘ ${ }^{1}$ ve Beyza Nur SAFI' ${ }^{2}$
}

$\ddot{\mathrm{O} z}$

Bu çalışmada İngiltere, Japonya, Norveç, Finlandiya, Singapur, Rusya ve Türkiye'deki mevcut eğitim sistemlerinin karşılaştırmalı olarak incelenmesi amaçlanmıştır. Araştırmada kullanılan genel karşılaştırma ölçütleri; eğitim felsefesi, eğitim sisteminin genel yapısı, öğrenme-öğretme ortamları ve eğitimde ölçme değerlendirme uygulamaları boyutlarıdır. Araştırmada Türkiye ile birlikte uluslararası TIMSS ve PISA sınav sonuçlarına göre başarılı olan ülkelerin (İngiltere, Japonya, Norveç, Finlandiya, Singapur ve Rusya) eğitim sistemleri incelenmiştir. Araştırma da nitel araştırma yönteminden bütüncül çoklu durum araştırması desenine uygun olarak gerçekleştirilmiştir. Verilerin elde edilmesinde nitel veri toplama yöntemlerinden doküman incelemesi kullanılmış ve veriler betimsel analiz yöntemiyle çözümlenmiştir. Araştırmadan elde edilen veriler doğrultusunda Türkiye, İngiltere, Japonya, Norveç, Finlandiya, Singapur ve Rusya eğitim sistemleri incelenerek ulaşılabilen veriler eğitim felsefesi, eğitim sisteminin genel yapısı, öğrenme-öğretme ortamları ve eğitimde ölçme değerlendirme uygulamaları boyutlarında karşılaştırılmış, benzerlikler ve farklılıklar ortaya konulmuştur. Türkiye'nin PISA sınavındaki durumu tartışllarak İngiltere, Finlandiya, Japonya, Norveç, Singapur ve Rusya örneğiyle ilgili olarak önerilerde bulunulmuştur.

Anabtar Kelimeler: Türk Eğitim Sistemi, Karşılaştırmalı Eğitim, İngiltere, Japonya, Norveç, Finlandiya, Singapur, Rusya, Türkiye

\section{A Comparative Analysis of England, Japan, Norway, Finland, Singapore, Russia and Turkey Education Systems}

\section{Abstract}

This study is aimed to examine comparatively the existing education systems in England, Japan, Norway, Finland, Singapore, Russia and Turkey. General comparison criteria used in the research philosophy of education, general structure of the education system, learning-teaching environments and measurement and evaluation practices in education. The education systems of the countries that were successful according to the results of the international TIMSS and PISA exams, together with Turkey, were examined in the study. The research was also carried out in accordance with the holistic multiple case research design from the qualitative research method. Document analysis ,one of the qualitative data collection methods, was used to obtain the data, and the data were analyzed with the descriptive analysis method. With the data obtained from the research, the education systems of Turkey, England, Japan, Norway, Finland, Singapore and Russia were examined in line, the data that could be reached were compared in terms of education philosophy, general structure of the education system, learning-teaching environments and assessment and evaluation practices in education, and similarities and differences were revealed. Turkey's situation in the PISA exam was discussed and suggestions were made regarding the example of England, Finland, Japan, Norway, Singapore and Russia.

Key Words: Turkish Education System, Comparative Education, England, Japan, Norway, Finland, Singapore, Russia, Turkey

\section{Atıf İçin / Please Cite As:}

Özerbaş, M. A. ve Safi, B. N. (2022). İngiltere, Japonya, Norveç, Finlandiya, Singapur, Rusya ve Türk eğitim sistemlerinin karşılaştırmalı olarak incelenmesi. Manas Sosyal Araştırmalar Dergisi, 11(1), 63-80.

Geliş Tarihi / Received Date: 4.09.2021

Kabul Tarihi / Accepted Date: 5.10.2021

\footnotetext{
${ }^{1}$ Prof. Dr. - Kırgızistan-Türkiye Manas Üniversitesi, marif.ozerbash@manas.edu.kg

iD ORCID: 0000-0002-1612-9349

2 Yüksek Lisans Öğrencisi - Gazi Üniversitesi Eğitim Fakültesi, bbeyza718@gmail.com

(iD) ORCID: 0000-0002-3905-5346
} 


\section{Giriş}

Eğitim sistemleri ülkelerin yetiştirmek istedikleri insan profiline göre şekillenmektedir. Bu bağlamda ülkeler eğitim vizyonlarını ve bu vizyon kapsamında eğitim uygulamalarını gelecekte yetiştirecekleri nitelikli bireylerin taşımasını istedikleri özelliklere göre yapılandırmaktadır. Ülkelerin eğitim sistemlerindeki farklılıklar ve bu farklılıkların incelenmesi karşılaştırmalı eğitim dalını ortaya çıkarmıştır. Karşılaştırmalı eğitim; farklı toplum ve dönemlerde uygulanan, eğitim sistemlerini birlikte veya ayrı ayrı çeşitli yönlerden karşılaştırarak ortak ve yararlı taraflarının ortaya çıarılarak eğitim planlama ve uyarlamalarında faydalanılmaya çalışılan bir bilim olarak ifade edilmektedir (Demirel, 2012). Karşılaştırmalı eğitim araştırmaları ülkelerin eğitim sistemlerinin tanınmasını sağlamakla birlikte ülkelerin eğitim sistemlerini diğer ülkelerdeki uygulamalara göre revize etmelerine imkân sağlamaktadır.

Ülkelerin eğitim sistemlerindeki başarıları yapılan uluslararası sınavlarla değerlendirilmektedir. OECD tarafindan düzenlenen uluslararası sınavlardan birisi Uluslararası Öğrenci Değerlendirme ProgramıPISA'dır (Programme for International Student Assessment). 2000 yllindan itibaren uygulanan PISA da amaç OECD ülkeleri ve diğer (dünya ekonomisinin \%90’ı) ülkedeki belirli düzeyde eğitimini tamamlamış öğrencilerin mevcut toplumda yer alabilmeleri için bilgi ve beceri düzeylerinin ne ölçüde olduğunu saptamaktır (Şimşek, Tuncer ve Dikmen, 2018, s. 559). PISA sınavinın sonuçları ülkelerin eğitim sistemlerinin karnesi olarak görülmektedir. Bu sinavda başarılı olan ülkeler genel olarak diğer ülkeler tarafından incelenmekte ve gerçekleştirdikleri eğitim uygulamaları örnek alınmaktadır.

Ülkemiz de OECD ülkesi olarak PISA sınavına katılmaktadır. Ancak sınav sonuçlarına göre genel olarak ülkeler arasında alt sıralarda yer almaktadır. Bu durum ülkemiz eğitim sisteminin PISA'da başarılı olan ülkelerin eğitim sistemlerinden farklı yönlerinin incelenmesi gerekliliğini ortaya çıkarmaktadır. Erdoğan (2003, s. 265) Türk eğitim sisteminde başka ülkelerin deneyimlerinden yararlanarak yapılacak yeniliklerin daha kontrollü ve temelli olabilmesine katkı sağlayacağını belirtmiştir. Bu doğrultuda başarılı ülkelerin eğitim sistemlerinin incelenmesinin Türkiye'nin gelecekteki eğitim reformları adına önemli bir adım olduğu söylenebilir. Bu çalışmada günümüzde en gelişmiş ülkeler arasında yer alan, TIMMS ve PISA gibi uluslararası sınavlarda başarı gösteren İngiltere, Japonya, Norveç, Finlandiya, Singapur ve Rusya eğitim sitemleri ile Türkiye eğitim sisteminin; eğitim felsefesi, eğitim sisteminin genel yapısı, öğrenme-öğretme ortamları, eğitimde ölçme değerlendirme uygulamaları ve öğretmen yetiştirme sistemleri başlıkları altında karşılaştırmalı olarak incelenmesi amaçlanmıştır. Araştırmada ilgili ülkelerin mevcut eğitim sistemleri incelenerek ulaşılabilen genel veriler çeşitli boyutlarda karşılaştırılmış buna göre eğitim sistemlerinin karşılaştırılmaları yapılmıştır.

\section{Araştırmanın Amacı}

Bu çalışmada İngiltere, Japonya, Norveç, Finlandiya, Singapur, Rusya ve Türkiye'deki mevcut eğitim sistemlerinin belirlenen ölçütlere göre karşılaştırmalı olarak incelenmesidir. Bu genel amaca ulaşmak için aşağıdaki sorulara cevap aranmıştı:

1. İngiltere, Japonya, Norveç, Finlandiya, Singapur, Rusya ve Türkiye'de eğitim felsefesi nasıldır?

2. İngiltere, Japonya, Norveç, Finlandiya, Singapur, Rusya ve Türkiye'de eğitim sisteminin genel yapisı nasildir?

3. İngiltere, Japonya, Norveç, Finlandiya, Singapur, Rusya ve Türkiye'de öğrenme-öğretme ortamları nasildır?

4. İngiltere, Japonya, Norveç, Finlandiya, Singapur, Rusya ve Türkiye’de ölçme değerlendirme uygulamaları nasildir?

\section{Yöntem}

\section{Araştırma Modeli}

Araştırma nitel araştırma yönteminden bütüncül çoklu durum araştırması desenine uygun olarak gerçekleştirilmiştir. Durum araştırmaları, bir ya da birden çok olayın, ortamın, sosyal grubun ya da diğer birbirine bağlı sistemlerin detaylı bir şekilde incelendiği araştırma yaklaşımlarıdır (McMillan, 2000). Bu araştırmada bütüncül çoklu durum çalışması deseninin seçilmesinin sebebi ise, araştırmanın problemi doğrultusunda ilgili ülkelerin (İngiltere, Japonya, Norveç, Finlandiya, Singapur, Rusya ve Türkiye) mevcut eğitim sistemlerinin belirlenen ölçütlere göre kendi içinde incelenmesi ve daha sonra bu durumların karşılaştırılmasıdır. 


\section{Verilerin Toplanmas 1}

Araştırma verilerinin elde edilmesinde nitel veri toplama yöntemlerinden doküman incelemesi kullanılmıştır. Doküman incelemesi, araştırlması hedeflenen konu ile ilgili yazılı verilerin incelenmesidir. (Yıldırım ve Şimşek, 2006). Araştırma sürecinde konuyla bağlantılı literatür incelendikten sonra ülkelerin eğitim sistemlerinin hangi kriterlere bakılarak karşılaştırılacağına karar verilip bu kriterler çerçevesinde veriler toplanmıştır. Verilerin toplanması sürecinde uluslararası araştırma raporlarından (TIMMS, PISA vb.) ve ülkelerin resmi kurumlarından (Ulusal Eğitim Kurumları, Üniversiteler, Milli Eğitim Bakanlıkları vb.) elde edilen verilerden yararlanılmıştır.

\section{Verilerin Analizi}

Araştırmada elde edilen veriler betimsel analiz yöntemiyle çözümlenmiştir. Belirlenen ülkelerin eğitim sistemlerinin hangi kriterlere göre karşılaştırılacağı araştırmacılar tarafindan belirlenmiştir. Betimsel analiz yaklaşımı, verilerin araştırma sorularında ortaya konan temalara göre düzenlenmesine ve araştırmada kullanılan sorular veya ölçütler dikkate alınarak sunulmasına olanak vermektedir(Yıldırım ve Şimşek, 2006). $\mathrm{Bu}$ araştırmada İngiltere, Japonya, Norveç, Finlandiya, Singapur, Rusya ve Türkiye'nin mevcut eğitim sistemleri belirlenen bu ölçütlere göre incelenmiş ve daha sonra karşılaştırılmıştır. Araştırma kapsamında ilgili ülkelerin karşılaştırılmasından kullanılan kriterler; eğitim felsefesi, eğitim sisteminin genel yapısı, öğrenme-öğretme ortamları, eğitimde ölçme değerlendirme uygulamaları ve öğretmen yetiştirme sistemleridir.

\section{Bulgular}

\section{İngiltere, Japonya, Norveç, Finlandiya, Singapur, Rusya ve Türkiye'de Eğitim Felsefesi}

Medeniyet gelişmelere bağlı olarak hızlı bir değişim yaşamaktadır. Özellikle teknoloji ve bilimde meydana gelen değişimler buna örnek teşkil etmektedir. Bu gelişmelere bağlı olarak ülkeler çağın gereksinimlerini dikkate alarak, bireylerin eğitim anlamında gelişmelerine önem vererek bilgi toplumu haline gelmelerini amaçlamaktadırlar. Gelişmelerin takip edilmemesi bir anlamda uluslararası toplumda yerinizi alamamak, rekabet edememek ve bağımlı hale gelmek demektir (Ataünal, 2003). 21.yüzyllın toplumlara getirdiği bir sürü yenilik ve gelişmeler bulunmaktadır. Bunların insanlara kazandırılması için eğitime duyulmaktadır. Eğitim pek çok öğenin bir araya gelmesiyle oluşan bir sistemdir. Böyle bir sistemin bir felsefesi mutlaka bulunmaktadır.(Tutkun, 2010, s. 993). Eğitim, çok genel anlamda, insanı kültürel hayata hazırlayan tüm sosyal süreçleri içerir ve resmi ve düşünsel anlamda kişilerin değerler, yetenekler ve bilgi bakımından eğitildiği sosyal kurumlar olan okullarda yapılır (Gutek, 2017). Bu durumda bir öğretim programının etkili olabilmesi için amaçlarını doğru biçimde ortaya koyan bir eğitim felsefesine ve öğretim yaklaşımına sahip olması gerekir. Eğitim felsefesi, bir öğretim programının "Nasıl bir birey yetiştirmeliyiz?" sorusuna verdiği yanıttır.

Dünyada yapılan uluslararası PISA ve TIMMS gibi sınavlarda adını duyuran ülkelerin eğitim felsefeleri bu bağlamda merak edilmektedir. 20. yy başlarında pragmatist felsefe İngiltere ve Amerika'da ortaya çıkmıştır. Pragmatist felsefeye dayanan eğitim felsefesi ilerlemeciliktir (Aydın, 2012). Bu felsefe doğrultusunda eğitimde ses getiren ülkelerden biri olan İngiltere'nin eğitim felsefesinin ilerlemecilik olduğu söylenebilir. Uluslar Arası Gelişim Birimi (Department for Education, 2010) tarafından yayımlanan 20102015 eğitim stratejisinde, İngiltere'nin eğitime dair vizyonunun herkes için kalite temelli bir eğitim olduğu belirtilmektedir. Her okulun ve öğrencilerin koşullarında farklllık olabileceği düşüncesi ile okullara ulusal programı kendi şartlarına göre geliştirme imkânı verilmektedir. Aynı zamanda ülkede ilerlemeci eğitim felsefesinin savunduğu gibi öğrenci merkezli bir eğitim sistemi vardır. Bu eğitim sisteminin 1şı̆̆ında İngiltere eğitiminin amacı, eğitim standartlarını yükselterek ekonomik olarak büyümeyi ve halkın yaşam şartlarını iyileştirmek; hayat boyu öğrenmeyi teşvik ederek eğitim öğretimde mükemmelliği; seçenekleri ve çeşitliliği arttırarak yüksek dereceli ve uygun iş olanakları oluşturmaktır (Eurydice, 2006).

İngiltere gibi uluslararası sınavlarda başarı gösteren Japonya'nın eğitim felsefesinin temeli ise Meiji restorasyonundan ve 2. Dünya Savaşından sonra yapılan reformlardan gelmektedir. Bu açlım doğrultusunda Japonya dünyanın en yüksek standartlı eğitimlerinden ve en yüksek okuma yazma oranlarından birine sahip olmuştur (OECD, 2015). Meiji restorasyonunu 1şı̆̆ında 1947 yılında kabul edilen ve halen yürürlükte olan Temel Eğitim Kanunu'nda eğitimin amac1 "Barışsever ve demokratik bir devlet olarak insan haklarına saygılı bir toplum ile kendine güveni tam vatandaşlar yetiştirmek" şeklinde ifade edilmiştir. Ayrıca kanun, ırk, inanç, cinsiyet, sosyal durum ve ailenin ekonomik durumuna göre bir ayrım 
yapılmasını yasaklamış yani eğitimde firsat eşitliğini temel ilke olarak kabul etmiştir (Demirel, 2000). İngiltere ve Japonya gibi eğitim felsefeleri ve eğitim amaçları 21. yüzyıl becerilerinden uzak kalmadan eğitim platformlarında ve dünyada önemli yer edinen ülkelerden Singapur'da da öğrencilerin yeteneklerini keşfetmelerini, tam potansiyellerini gerçekleştirmelerini ve yaşam boyu öğrenmeye istekli olmalarını sağlayarak her çocukta en iyisini ortaya koymayı amaçlamaktadır. Tüm çocukları yetiştirmek ve 21. yüzyılda gelişmek için gerekli yetenek ve tasarruflara sahip olduklarından emin olmak için yetkinliklerin, değerlerin ve karakterin kalıcı bir şekilde geliştirilmesi üzerine odaklanmışır (ESD, 2018).

$\mathrm{Bu}$ amaçla oluşturulmuş eğitim hedeflerinin istenen çıtktları ilk olarak 1997 y1lında oluşturulmuş ve 2009 yılında Singapur Eğitim Bakanlığı tarafından yayınlanmıştır. Eğitim sisteminden beklenen amaçlar; güçlü düşüncelere sahip, kendini tanıyan, bağımsız ve eleştirel bir şekilde düşünen ve etkili bir şekilde iletişim kuran, kendine güvenen, kendi öğrenmesi için sorumluluk alan, öğrenmek için araştıran, sorgulayan ve sebat eden, kendini yöneten bir ve takımlarda etkin bir şekilde çalışabilen, uygun riskleri alan ve inisiyatifi uygulayan, yenilikçi ve mükemmeli kılan aktif bir katılımcı ve aynı zamanda güçlü bir yurttaş bilincine sahip, çevresindeki diğer insanların yaşamlarını iyileştirmede aktif rol alan bireyler yetiştirmektir. İlerlemecilik eğitim felsefesini temel alan Singapur birçok açıdan Finlandiya eğitim felsefesiyle benzerlik göstermektedir. Finlandiya eğitim felsefesinin temelinde eşitlik, esneklik, yaratıcıllk, öğretmenlerin profesyonelliği ve karşılıklı güven ilkelerine dayanır. Eğitimin amacı; öğrencilerin insani ve ahlaki değerlere sahip bireyler olmalarını ve yaşamları boyunca kullanacakları bilgi ve becerilere sahip olmalarını sağlamaktır. Eğitim topluma medeniyet ve eşitlik kavramlarını aşılamalı ve öğrencilere eğitimin şart olduğu, kendilerini yaşamları boyunca geliştirmeleri gerektiği bilincini vermelidir. Eğitimin bir diğer amacı tüm ülkede firsat eşitliğini sağlamaktır (Eurydice, 2011).

Bahsedilen bu ülkelerde olduğu gibi Rusya da tarihi geçmişinde önemli dönüm noktaları yaşamıştır. Çarlık Rusya'nın yıkılmasının ardından 1917 yıllında Sovyet Sosyalist Cumhuriyetler Birliği’nin (SSCB) kurulması ve 1991'de bu cumhuriyetler birliği yıkılarak Rusya Federasyonu'nun kurulması tabi ki eğitim felsefelerini de etkilemiştir. Rusya'da meydana gelen bu tarihi meseleler ve sosyalist görüş Sosyal yapılandırmacılığın kuramcısı Rus eğitim bilimci L. S. Vygotsky'nin bilişsel yapılandırmacıııkta adı sıklıkla geçen J. Piaget'e eleştirel bakmasına bu doğrultuda çocukların bilişsel gelişimine yönelik deneysel araştırmalarda, bilişsel süreçlerden okulun etkisinin olmamasını eleştirerek, öğrenmenin etkiletişimle, model alarak, zihindekileri açığa çıkaracak ortamlar oluşturulmasıyla ve bunları yaparken de dil ve kültür işlevselliğinin de önemini vurgulamıştır (Aydın, 2012). Rusya Federasyonu'nun eğitim amacı evrensel değerlere ve hümanist özelliklere sahip, insan hak ve özgürlüklerine saygılı, vatandaşlık, yurttaşlık bilgisine sahip, kişisel gelişime açık, çevre ve doğa sevgisi ile vatan ve aile bilincine sahip bireyler yetiştirmektir (Aldemir, 2010).

Bununla birlikte, vatandaşlarının genç neslinin eğitim içeriğinin ve koşullarının iyileştirilmesinde eğitim sisteminin (aile, toplum, devlet, eğitim, bilimsel, geleneksel dini ve diğer kamu kuruluşları, kültür ve spor organizasyonlanı, medya, iş toplulukları) konularının işbirliğinin geliştirilmesi, tüm çocukların kültürel değerlere erişebilmesi için eşit firsatlar yaratmak ve eğitim sisteminde eğitimin geleneksel Rus kültürel, manevi, ahlaki ve aile değerleri ile uygunluğunun sağlanması amaçlanmaktadır. Genel olarak değerlendirildiğinde bu ülkelerin eğitim felsefelerinin temelinde yapılandırmacı yaklaşım yatmaktadır. Yapılandırmacilık öğrenme sürecinde yaparak yaşayarak öğrenmeye vurgu yapmakta ve öğrenci merkezli bir yaklaşım özelliği taşımaktadır.

Pragmatik felsefeye olan dayanağı bilgi, teknoloji ve sanayi toplumlarının iş gücü ihtiyacını karşılayan felsefe faydacı ve doğrucudur. Burada iş gücünden kast edilen insanın fiziksel gücünden ziyade bu felsefenin temelinde yer alan bireye düşünme ve yaratıcllk, eleştiri, analiz, sentez ve yansitıcı düşünme becerilerini sağlayan beyin ve zekâ gücüdür. Bu felsefeye göre birey biricik ve tektir. Bireyin yeri ve varllğı başka şeyle doldurulamaz. Bireyin öznel zihni nesneyi var ya da yok kılar. Bu düşünce pragmatik felsefenin öznel idealimin bir ürünü olduğunu göstermektedir (Wells, 2003). Öznel idealizme göre bireyin zihninde olmayan nesne yoktur. Öznel idealizmin öncüsü George Berkeley “ Var olmak algilanmış olmaktır.” der. Pragmatizm de bundan yola çıkarak var olmak faydalı olmaktır, eğer bir nesne faydalı değil ise o aslında yoktur demektedir (Wells, 2003). Pragmatizm farklı ideolojilerle beslenirken John Dewey de pragmatizmi eğitim felsefesi olarak ilerlemecilik eğitim felsefesi kuramını geliştirerek günümüzde birçok ülkenin ve yukarıda bahsedilen ülkelerin eğitim felsefi temelini oluşturmuştur. Temeli pragmatizmden gelen bu yaklaşımda "Okul yaşamın kendisi olmalıdır." Okul insanı yararlı ve yetenekli yapar, daha sonra hayatlarında karşılarına çıkacak sorunlara yardım edecek ve onların hayatta daha istekli olmasını sağlayacaktır." 
Bu ülkelerden farklı olarak ilerlemecilik eğitim felsefesinin dışında dini temelleri göz ardı etmeyen Norveç'in eğitim amac1; okul ile aile işbirliği içerisinde öğrencilere Hıristiyanlık ve etik eğitim vererek yeteneklerini hem ruhsal hem de bedensel olarak geliştirecek bilgiler verip içtimar hayatta ve ailede özgüveni yüksek bireyler olarak gelişmelerini sağlanmak" şeklinde ifade edilmiştir. Norveç tarafindan desteklenen ve uluslararası Din ve İnanç hürriyetleri Oslo Koalisyonu (Oslo Coalation Freedom of Religion or Belief) adlı sivil toplum kuruluşu da disiplinler ve uluslararası olarak okul eğitimi aracillğıyla din ve inanç özgürlüklerini geliştirmek için çalş̧maktadır (Jackson, 2004, s. 3). Norveç’te okul, öğrencilerde düşünsel ve vicdani olarak geliştirmeye, öğrenciler ve öğretmenler arasında iş birliği oluşturmaya imkân sağlar. Ayrıca tüm öğrencilerin kilit beceriler geliştirmeli ve eğitimleri boyunca hem zorluklarla yüzleşmeli hem de bir başarı duygusu yaşamalıdırlar (Çayır, 2015).

Norveç Eğitim ve Araştırma Bakanlığı'nın sayfasında: "Norveç okul sistemi, eşitlik ilkelerine dayanmakta ve kapsayıcı bir ortamdaki herkes için uyarlanmış öğrenmeye dayanmaktadır" denmektedir (Regjeringen, 2020). Fakat kendi sayfasında yayınladığı müfredatının 7, 8, 9, 10 ve 11. sayfalarında yer alan İlk, Orta ve Yetişkin Eğitimi Çekirdek Müfredatının 7. sayfasında "The spiritual human being" (Manevi İnsan) başıı̆ı alıtında yer alan açıklamalarda "Eğitim, herkesin görüşüne dayanmalıdır. Eğitim, temel Hristiyan ve hümanist değerlere dayalı olacaktır. Eğitim etik kurallara açıllı getirmeli ve gerekçelendirilmelidir. Bunlar sırayla İncil benzetimleriyle, ayrıca resimlerle de açıklanabilir." ifadeleri eşitlik ilkeleriyle ve kapsayıcı bir ortamda uyarlanmış öğrenme düşüncesiyle bağdaşmamaktadır. Ülkemizde 1824 yllında II. Mahmut ile kabul edilen zorunlu eğitimin Norveç'te 1937 yllında kabul edildiği ve 2012 yllına kadar herkesin kiliseye üye olması zorunlu olduğu Norveç eğitim felsefesi, Antik Yunan Felsefesi altyapısında modern eğitim anlayışı izlenimi veren Evanjelik Lutheran sistemine uyarlanan taraflı düşünce yapısı hissiyatı oluşturmaktadır.

Bahsedilen bu önemli altı ülkede olduğu gibi Türkiye de 2005 öğretim programında yapılandırmacı yaklaşımı temele almıştır. Bu sayede bireyi merkeze alan eğitim içerikleri (kazanımlar, etkinlikler) planlanmıştır (Phillips ve Soltis, 2004). Bu bağlamda Türk eğitim sisteminin ilerlemeci eğitim felsefesine sahip olduğu söylenebilir. Ayrıca 2017 yllında taslak olarak sunulan ve 2018 yllında yayınlanan öğretim programında eğitim felsefesinin önem ve gerekliliğinden derinlemesine bahsedilirken eğitim felsefesinin net bir şekilde açıklanmadığı görülmüştür. Türk eğitim sistemi akılcı bir felsefeye dayanmaktadır.

İngiltere, Japonya, Finlandiya, Rusya ve Singapur'un eğitim felsefeleri temelde ilerlemeci eğitim felsefesinden doğan öğrenciyi merkeze alan bir yaklaşım olan sosyal yapılandırmacılık yaklaşıma uygun olduğu görülmektedir. Sosyal yapılandırmacılık bahsedilen bu ülkeleri etkilediği gibi Türkiye'de de öğretimde, öğrencinin öğrenmede aktif rol oynadığı, değerlendirmenin süreç içinde yapıldığı öğrencilerin araştırma yapmaya yönlendirilmesi 2018 programı ile uygunluk göstermektedir. Eğitim amaçlarımızın temelinde ülkemizdeki eğitim felsefesinde hedeflendiği gibi öğretmen sınıfta eğitimin ana kaynağı değil öğrenciyi yönlendiren olarak bir görev almaktadır. Aynı şekilde öğrencinin araştıran, keşfeden olmasının beklendiği gibi öğrenciye yüklenen görevlerde bahsedilen ülkelerin eğitim felsefeleri ve amaçları ile ülkemiz 2018 programı arasinda ortak noktalar bulunmaktadır.

Bu ülkelerin içerisinde Türkiye ile benzerlik göstermeyen Norveç ilerlemecilik eğitim felsefesinin yanı sıra varoluşçu teolojinin etkisinde olduğu görülmüştür. Varoluşçu teoloji kavram1, tıpk1 varoluşçuluğun bilimde, ahlakta, estetikte, sanatta, edebiyatta, şiirde, sinemada yaptı̆g etkiye benzer bir şekilde, dinde yaptığ1 etki neticesinde oluşmuş bir kavramdır. Varoluşçuluk düşüncesinin temeli, insan varoluşunun somut yönlerinden hareket etmek ve bu suretle de yaşamdaki yüz yüze geldiğimiz olaylar karşısındaki tutumlarımızı irdelemeye yöneliktir. Din meselesi de insanın yüz yüze geldiği kaçınılmaz bir konu olması nedeniyle varoluşçuluğun atlayamayacağı bir meseledir (Ertürk, 2012). Varoluşçu teolog olarak P. Tillich, rasyonel teolojilere ve geleneksel teizme karşı Varoluşçu Teolojiyi savunmuştur Onun bu karşı duruşu adeta başkaldırı niteliğindedir. Kısaca O'nun varoluşçu teoloji anlayışını şöyle izah edebiliriz: İnsanı dini bir varlık olarak (Homo Religious) olarak tanımlaması, şartsızın (Tanrının) zorunluluğunu gerektirir. Bu da dini sembole ihtiyacı zorunlu kilar. Dini semboller, salt kavramsal alanın ötesindeki insani boyutu ifade ederler. Dini sembollerde insanı nihai olarak ilgilendiren sonsuz gerçekliğe bir işaret ve ima vardır. Burada rasyonel teolojideki saf aklın soyutlamalarından oluşan paradigmasına karşlık P. Tillich, dini sembollerin somut gerçekliklerini ortaya koymaktadır. Soyut ilkeler yerine somut dini semboller (Çınar, 2007). 


\section{İngiltere, Japonya, Norveç, Finlandiya, Singapur, Rusya ve Türkiye’de Eğitim Sisteminin Genel Yapis1}

Bilim ve teknolojinin hızla değiştiği küresel çağda kalkınmanın temeli eğitim olarak görülmektedir. Bireyin eğitimi bu bağlamda önemli görülmekte ve yalnızca ulusal değil; aynı zamanda uluslararası alanda değerlendirme yoluna gidilmektedir. Bu uluslararası değerlendirme sınavlarından biri olan PISA, belirli aralıklarla lise grubu öğrencilerinin bilgi ve beceri düzeylerini araştırmaktadır. Bu kapsamda son yapılan 2015 PISA sınav sonucunda sıralamada başarılı olmuş Singapur, Finlandiya, İngiltere, Norveç, Japonya ve Rusya'nın eğitim sistemlerinin genel yapısını anlamak önemlidir. 2015 PISA sınavında birinci olan Singapur, Asya eğitim sistemleri arasında öne çıkmış olup eğitim sisteminden Eğitim Bakanlı̆̆ (Ministry of Education-MOE) sorumludur. Eğitim Bakanlığı, eğitim politikalarının oluşturulmasından ve uygulanmasindan sorumlu idari organ olup liderlik ve insan gücünü sürekli ve tutarlı tek doğal kaynak olarak görmektedir. Eğitim Bakanlığının misyonu; ulusun geleceğini yönlendirecek gençleri şekillendirmektir (Ministry of Education, 2018a).

Okullaşma oranın neredeyse \%100 olduğu Singapur'da (Levent ve Yazıc1, 2014, s. 121) öğrenciler altı yıllık ilkokul (Primary) ve dört ile beş yıllık ortaöğretim (Secondary) eğitimi almaktadırlar. Singapur eğitim sisteminde yükseköğretim (Post-Secondary); ön lisans kurumlar1 (Junior Colleges), üniversiteler, politeknikler (Polytechnic) ve teknik eğitim enstitülerinden (Institute for Technical Education) oluşmaktadır(MOE, 2018a; OECD, 2010). Güneydoğu Asya'da çok kültürlü bir yapiya sahip olan Singapur'da zorunlu eğitim ücretsizdir ve 6-15 yaş arasını kapsamaktadır. Ancak 2019'dan itibaren geçerli olmak üzere, zorunlu eğitim çerçevesi ayrıca 1 Ocak 2012'den sonra doğmuş orta-şiddetli özel eğitim ihtiyaçları (Special Educational Needs-SEN) olan çocukları da içermektedir. (CE, 2018; MOE, 2018b). Bütün öğrenciler ilkokulun sonunda "İlkokul Bitirme Sınavı"na tabi tutulmakta ve sınav sonucuna göre ortaöğretim düzeyindeki üzere farklı kurlarda eğitim önerilmektedir. Bu kurlardan yalnızca normal kurlardaki öğrenciler kuru bitirme sınavı sonrasında ve 1 yıllık hazırlık eğitimi aldıktan sonra üst seviye için sınava girebilir (Bakioğlu ve Göçmen, 2013, s. 127). Yillardır, PISA sınavlarında birinci olan ve başarılı eğitim sistemlerinden birine sahip olduğu kabul edilen Finlandiya (Søby, 2015) eğitiminin temel ilkelerinden biri, tüm insanların yüksek kaliteli eğitim ve öğretime eşit erişime sahip olmaları gerektiğidir (Ministry of Education and Culture [MEC], 2017). Finlandiya'da Eğitim ve Kültür Bakanllğı, eğitim, bilim, kültür, spor ve gençlik politikalarının geliştirilmesinden ve bu alanlarda uluslararası işbirliğinden sorumludur. Bakanlığın amacı, vatandaşlara eğitim ve kültürel hizmetler yoluyla kişisel gelişim olanakları sağlamak, işgücü piyasasında ihtiyaç duyulan becerileri sağlamak, ulusal kültürü güçlendirmek ve uluslararası işbirliğini teşvik etmektir (MEC, 2017).

Finlandiya'da ulusal eğitim yönetimi iki düzeyde gerçekleşir. Eğitim politikası Eğitim ve Kültür Bakanlığının sorumluluğunda olmasına rağmen eğitimde yerel özerklik oldukça yaygındır. Çoğunlukla belediyelerin sorumluluğunda olan yerel yönetimler; fon tahsisi, personel alımı ve yerel müfredat kararlarını verirler. Belediyeler, karar alma yetkisini okullara devretme özerkliğine de sahiptir. Finlandiya'da belediyeler en çok okul öncesi ve temel eğitimin ihtiyacını karşılamaktadır (Education in Finland, 2017; MEC, 2017). Finlandiya eğitim sistemi; erken çocukluk eğitimi ve bakımı, okul öncesi eğitimi, zorunlu eğitim olan temel eğitim, lise eğitimini kapsayan ortaöğretim ve yükseköğretim olmak üzere dört temel ögretim kademesinden meydana gelmektedir. Zorunlu eğitim ise 9 ylllık bir eğitim-öğretim döneminden oluşmaktadır (NCEE, 2019). Zorunlu eğitim dönemindeki öğrenciler sağlık, yemek, bilgisayar ve yazıc1 kullanımı, geziler gibi etkinliklerden ücretsiz faydalanmaktadır (Malaty, 2006, s. 59).

Firsat eşitliğinin ön planda olduğu Finlandiya'da okul öncesi ve yükseköğretim dâhil, her seviyede ücretsiz eğitimin verildiği adil bir sistem sunulmaktadır (Legco, 2019). 2015 yllında ocak ayında çıkmış olan yasayla okul öncesi eğitim de zorunlu hale gelmiştir ve 6 yaşına gelmiş tüm çocukları kapsamaktadır. Böylelikle zorunlu eğitim bir sene okul öncesi, 9 sene $(6+3)$ kapsamlı okul ile birlikte 10 sene olmuştur. Yani eğitim 6 yaşında başlar, 10 yıl sürer ve temel eğitim adı verilen tek yapılı bir sistemde gerçekleştirilmektedir (MEC, 2017). PISA sınavlarında Finlandiya kadar adından söz ettiren Japonya'da ise eğitim her 10 yllda bir güncellenmektedir (Aoki, 2017). Eğitimin tüm faaliyetleri Eğitim, Kültür, Spor, Bilim ve Teknoloji Bakanlığı (MEXT) sorumluluğundadır. Bakanlık, yeni eğitim kurumlarının kurulmasına karar verir, ulusal eğitim kurumlarının bütçelerini ve özel kurumlara verilen hibeleri belirler (Nuffic, 2015). Japonya'daki okul sistemi, üç senelik isteğe bağlı anaokulu, 6 sene ilkokul, 3 sene alt ortaokul ve 3 sene üst ortaokuldan oluşur. 
Ancak ülkede zorunlu olarak 9 yıllık bir eğitim alınmaktadır. Bunun 6 yll ilkokul ve 3 yllı ortaokuldur. Alt ortaokulu bitirmiş öğrenciler, yaklaşık on altı yaşındayken, üst ortaokula başvuruda bulunabilirler (NCEE, 2019). Alt ortaokul bitirdikten sonra öğrenciler 9 yıllık zorunlu eğitimlerini tamamlar ve ortaokuldan ayrilma sertifikası alırlar (Nuffic, 2015). Japonya da üç farklı okul bulunmaktadır. Bunlar kendi arasında ulusal, kamu ve özel okul olarak ayrılmıştır (İpek, 2001, s.175). Japon eğitim sistemi her 10 yılda bir gözden geçirilmekte olup 2020 yılının ilkokul eğitim programı hazırlanmıştır. Ayrıca eğitim sisteminde küreselleşme göz önüne alınmış ve İngilizce eğitimi 5. Sınıftan itibaren düzenli olarak öğretimi yapılmıştır (Aoki, 2017). PISA'da başarılı bir diğer ülke olan İngiltere'de eğitim sistemine ilişkin genel sorumluluk İngiltere Hükümeti Eğitim Bakanllğı’na aittir (Eurydice, 2018). Eğitim Bakanlığı, herkese birinci sinıf eğitim sağlayarak potansiyellerine ulaşma ve daha nitelikli bir yaşam sürdürme şansına sahip olmasını amaçlamaktadır. İngiltere genelinde beş eğitim aşaması vardır: okulöncesi, ilkokul, ortaokul, ileri eğitim (FE) ve yükseköğrenim (Education System in The UK, 2019). İngiltere'de zorunlu eğitim 5-16 yaşlarını kapsar; ilköğretim 5-11 yaş, dönemi olup 5-7 yaş arasında okulöncesi olan ilk aşamayi 7-11 yaş ikinci aşamayı oluşturmaktadır. Ortaöğretim ise 11-16 yaşlarını kapsarken üçüncü aşama olarak kabul edilen 1114 yaş aralı̆̆ı ile dördüncü aşama 14-16 yaş aralığını içermektedir (NFER, 2019). Öğrencileri devlet tarafindan finanse edilen ilk veya orta öğretim kurumları ücretsizdir (Eurydice, 2007).

Eğitim sisteminde bölgesel olarak düzenleyen bir diğer ülke olan ve güçlü bir ekonomi ile sosyal refah sistemine sahip olan Norveç, eğitim alanında dünyadaki en yüksek harcama yapan ülkeler arasında yer almaktadır (DET, 2011). Norveç’te devlete bağlı okullarının işleyiş ve yönetiminden kendi bölgesindeki belediyeler sorumludur. Norveç eğitiminin yapı ve işleyişi devletin ve meclisin belirlediği kanunlara uygun olarak yürütülmektedir. Eğitim hakkında en üst karar alma merci, Eğitim ve Araştırma Bakanlığı olmasına rağmen temel eğitimi ve orta öğretimi yerel yönetimler, yükseköğretimi ise Eğitim ve Araştırma Bakanlı̆g1 yönetmektedir. Bakanlık ayrıca araştırma ve entegrasyondan sorumludur (Regjeringen, 2020). Hayat boyu öğrenme bakış açısıyla düzenlenen Norveç eğitim sisteminde zorunlu eğitim 6-16 yaş arasını kapsar ve zorunlu olmasa bile ortaögretim eğitimi yasal bir haktır. 10 ylllık zorunlu eğitim ilkokul (Barnerinnet) ve ortaokul (Ungdomstrinnet) olup iki ana bölüme ayrilır (Eurydice, 2018a).

Zorunlu ilkokul 1-4. kademe birinci kademe, ilkokul 5-7. sinıflar ikinci kademe ve ortaokul 8-10. sinıflar üçüncü kademe olmak üzere toplamda üç kademeden oluşmaktadır (Just Landed, 2019; OECD, 2013). Ancak bu durum bazı okullar için 3 kademe halinde iken, bazı okullar da ilkokul ve ortaokul olarak 2 kademe olmaktadır (Avc1 ve Toy, 2018, s. 39). Ortaöğretime (Videregående Opplæring) giriş için yaş sınırı ve zorunluluk bulunmamaktadır. Fakat öğrencilere tercih imkânı sunularak genel ve mesleki liselere başvuru yapabilmektedirler (Eurydice, 2018a).

Norveç, eğitim sisteminin her kademesinde büyük fonlara sahiptir; kamu ve özel eğitim kurumlar1 fonlarının çoğunu kamu kaynaklarından almaktadır ve eğitim- ilköğretim öncesi dönem hariç- ücretsizdir (OECD, 2013). Okul yönetimi ve liderliğin tüm ülke için geçerli olan ulusal, bölgesel ve yerel yönetim yapısının bir parçası olan Norveç’te (Boavista, 2017, s. 113) "herkes için eğitim" eğitim politikasının temel prensibidir. Çocuklar ve gençler, nerede yaşadıklarına, cinsiyetlerine, sosyal ve kültürel geçmişlerine veya özel gereksinimlerine bakılmaksızın, eşit eğitim hakkına sahip olmalıdır (Regjeringen, 2020). Eğitim ve Bilim Bakanlığı, PISA'da (2015) finansal okuryazarlık alanında değerlendirilen 10 OECD ülkesi ve ekonomisinin ortalamasının üzerinde puan alan Rusya Federasyonunun (OECD, 2015), federal bir yürütme organıdır. Bakanlık, araştırma, bilimsel ve mühendislikle birlikte inovasyon çabalarının yanı sıra eğitim, gençlik politikası, çocuk yetiştirme ve sağlığın iyileştirilmesi,- sosyal hakların korunması ve çocuk haklarının korunmasinda devlet politikası ve yasal düzenlemeleri uygular.

Eğitim Bakanlığına ek olarak, Rusya Federasyonu'nun kurucu bölümlerinde eğitim organları ve yerel (belediye) idari organlar eğitimin gelişmesinden sorumludur. Bu organların tümü, kurdukları eğitim kurumlar1 için idari sorumluluklara sahiptir (UNECOPES, 2001; Volkava, 2017). Rusya Federasyonu anayasanın 43. maddesine göre genel eğitime erişim her Rus vatandaşının güvence altına alındığı bir hak olup devlet okullarında ücretsiz olarak verilmektedir. Rusya Federasyonu'nda eğitim, zorunlu temel eğitim ve devamında yüksek eğitim olarak ayrılır (Nazarova, 2014). Herkes 4 yılllk ilkokul ve 5 ylllık ortaöğretimin ilk aşamasından oluşan zorunlu 9 ylllık bir eğitime katılır. 4 yıllık ilköğretimi tamamladıktan sonra, öğrenciler 5 ylllık nominal süreye sahip ve zorunlu eğitim süresini tamamlayan orta öğretimin ilk aşamasına girerler (Nuffic, 2015). 
Tablo 1. Türkiye'de Dönemlere Göre Net Okullasma Oram (\%) (MEB, 2021)

\begin{tabular}{lllll}
\hline Dönem & İlkokul & Ortaokul & Ortaöğretim & Yükseköğtetim \\
\hline $2017-2018$ & 91.5 & 94.5 & 83.6 & 45.6 \\
$2018-2019$ & 91.9 & 93.3 & 84.5 & 44.1 \\
$2019-2020$ & 93.6 & 95.9 & 85 & 43.4 \\
\hline
\end{tabular}

Tablo 1'e göre Türkiye'de 2019-2020 yllında yayınlanan istatistiklere örgün öğretim döneminde net okullaşma oranları ilkokul, ortaokul ve orta öğretim düzeylerinde önceki yıllara göre artış göstermiştir. Ancak yükseköğretim düzeyinde ise söz konusu oranlar son ylllara oranla düşüş göstermektedir.

2017 verilerine göre lise dönemindeki öğrenciler için net okullaşma oranı \%88'dir. OECD ülkeleriyle okullaşma oranları karşılaştırıldığında Türkiye bu ülkelerin çok gerisinde kalmaktadır. Her ne kadar yıllara göre lise mezuniyet oranımız artış gösterse de OECD ülkeleri arasında alt sıralarda yerimizi almaktayız (MEB, 2017)

2012-2013 eğitim öğretim döneminde Türkiye'de zorunlu eğitim 8 yıldan 12 yıla çıkarılmıştır. Daha önce 5+3 (İlkokul-ortaokul) șeklinde uygulanan model, 4+4+4 (4 sene ilkokul, 4 sene ortaokul ve 4 sene lise ) şeklinde kademelendirilmiştir. Okula kayıt olma yaşı daha önce 72 ay iken yeni sistemde 66 ayını dolduran çocukların okula kayıt olmaları zorunlu hale getirilmiştir. Eğitim, öğrenim çağında bulunan kız ve erkek çocuklar için zorunlu ve devlet okullarında parasızdır. Finlandiya da zorunlu eğitim kapsamına giren okulöncesi eğitim Türkiye'de de diğer ülkeler gibi zorunlu görülmemektedir. Karşılaştırmalı olarak incelenen ülkeler arasında zorunlu eğitimin en yüksek yıla sahip olduğu ülke Türkiye'dir.

\section{İngiltere, Japonya, Norveç, Finlandiya, Singapur, Rusya ve Türkiye'deki Öğrenme-Öğretme Ortamlarına Teknoloji Entegrasyonu}

Eğitimde teknoloji entegrasyonu, eğitim ve teknoloji kavramlarının daha ötesinde pek çok yapısal, pedagojik, ontolojik, anlamsal, teknik, felsefî ve sosyolojik süreci bünyesinde barındıran, kendine özgü yeni bir alan meydana getirmiştir. Bu değişim ve gelişim başta eğitim alanında olmakla birlikte yaşamın farklı süreçlerinde değişikliklere sebep olmuştur. Günümüzde Bilgi İletişim Teknolojileri (BİT) hızlı bir biçimde gelişmekte ve bu gelişen teknoloji yalnızca bilgisayar ve internetle kalmayıp akıllı telefonlar, tabletler veya etkileşimli tahtalara varıncaya kadar ögretme öğrenme ortamlarında yerlerini almaktadır (Demir, 2018). Çalışmanın bu bölümünde uluslararası sınavlarda başarılı olan bazı ülkelerin öğrenme öğretme ortamlarına teknolojinin entegrasyonu incelenmiş ve Türkiye ile kıyaslanmıştır. Çalışma kapsamında incelen ülkeler: İngiltere, Japonya, Finlandiya, Singapur, Norveç, Rusya ve Türkiye'dir. İngiltere, ilk ve ortaöğretim kurumlarını Eğitim Teknolojileri (ET) ile donatmak için 2003-2005 yılları arasında 50 milyon poundluk bir bütçe ayırmıştır. 2007 yllı itibariyle ülke genelindeki ilköğretim kurumlarının tamamının; orta dereceli kurumların ise \%98'inin ET teknolojisine sahip olduğu belirtilmektedir (Lai, 2010, s. 511). İngiltere'nin müfredatı BíT’e daha fazla odaklanmakta, onu kendi başına bir ders olarak görmeyip farklı konuları araştırmak için kullanmaktadır. Bununla birlikte, öğrencilerin daha fazla bilgi ve iletişim teknolojisine sahip olmaları, kodlama, programlama ve geliştirmeyi ögrenmeleriyle daha fazla vurgu yapılmaktadır. İnternetten, sanal ders kitaplarına, kaydedilen dersleri gözden geçirmeye kadar, eğitimin her yönü teknoloji tarafindan desteklenmektedir (Research report: UK, 2017).

Dünya’nın önemli teknoloji ihracatçısı Japonya'da da teknoloji eğitimi oldukça önem taşımaktadır. 1957'nin sonlarında Japon hükümeti tarafindan benimsenen politikalardan biri, 1958'den başlayarak tüm alt ortaöğretim okullarında zorunlu bir konu olarak teknoloji eğitimi olan "gijutsuka'nın" tanıtılmasıydı. Ortaokullarda teknoloji eğitiminin başlatılmasıyla birlikte mesleki eğitim seçmeli bir ders olarak ortaokul seviyesine taşınmıştır (Murata ve Stern, 2016). 21. yüzyıl becerilerinin giderek farkındalık yarattı̆̆ bu dönemde Japonya da daha ilkokul döneminde kodlama derslerini müfredata koymaya başlamıştır. Sınıflar bu amaca uygun olarak donatılmıştır. Anasınıfları da dâhil olmak üzere Japonlar, dijital çağı okul öncesinde tabletli eğitimle yakalamaya çalışmaktadır. Klasik yöntemlere ek olarak çocuklar tabletler aracıllğıyla resim çizmeye, boyama yapmaya ve çizdiklerini 3 boyutlu dijital görüntüsünü ekrana yansıtmay1 çok küçük yaşlarda yapmaya başlamaktır (İTEBS, 2018). Ayrıca Japonya Eğitim Bakanlığı, uygulamalı derslerden olan İngilizce için diğer ülkelere örnek olabilecek nitelikte bir proje planlamaktadır. Bu proje kapsamında, anadili İngilizce olan öğretmen açığını kapamak ve öğrencilerin sözlü becerilerini geliştirmek için yapay zekâ sahibi robotlardan yararlanmayı düşünmektedir. Bu yöntemle hem öğretmenlerin hem de öğrencilerin akıcı İngilizce konuşulması sağlanacaktır. Ayrıca Japonya'daki Vantan isimli bir özel lise müfredatına Dron ve Robotik Dersi eklemiştir. Dron mühendisliği konusunda artan yetişmiş insan kaynağı ihtiyacını

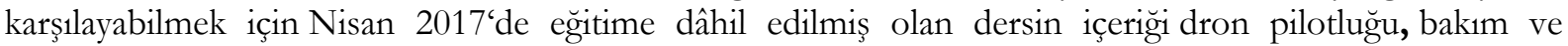


onarım, havacılık, radyo yayını kuralları ve bilgisayar programlama gibi konulardan oluşmaktadır. 3 yıl boyunca gösterilecek olan derste dron ve robotlarla çalısmanın avantaj ve dezavantajları öğretilmesi amaçlanmaktadır (Blaster, 2016).

PISA sinavlarında kendinden fazlaca söz ettiren Finlandiya'da ise dikkat çeken özellik birçok ülkenin eğitimde kullandıkları interaktif tahtalar, Avrupa ülkelerine göre daha az sıklıkla kullanılmaktadır. Her tür ve seviyedeki derslerde teknolojinin az kullanıldığı ülkelerdendir. PISA 2012 sonuçlarına göre ve Avrupa Komisyonu tarafindan yapılan araştırmalara göre Finlandiya'da beş öğrenciye bir bilgisayar düşmektedir. Finlandiya'da bilgisayar ve internet kullanımı konusunda okullar ve öğretmenler arasında oldukça farklılıklar vardır. Bazı okullarda akıllı tahtaları kullanıp oyunlar oynanırken bazı okullarda tüm okul için sadece birkaç bilgisayar bulunmaktadır. Yapılan araştırmalarda Finli öğrencilerin hemen hemen yarısı bilgisayar ve interneti derslerde hiç kullanılmadığı ortaya çıkmışır. Okullarda bilgisayar, tepegöz ve yansıtıcılar bulunmakta ancak kullanım sıklğıının düşük olduğu gözlemlenmektedir (Leino, 2014). Son yıllarda PISA ile eğitim camiasının gündeminden düşmeyen Singapur, öğrencilerin öğrenme ortamlarını zenginleştirmek ve dönüştürmek ve bilgiye dayalı bir ekonomide başarılı olmak için onları kritik yeterliliklerle donatmayı amaçlamaktadır. Singapur'da öğretmenler, yenilikçi öğretim uygulamaları geliştirmek için birbirleriyle ve paydaşlarla işbirliğ̣i yapmaktadır. Bilgi iletişsim teknolojilerinin müfredat entegrasyonlu kullanımı ile birlikte öğrencilerin öğrenme deneyimlerinin öğrenci merkezli olması eğitim teknolojilerinin odak noktasını oluşturmaktadır (MOE, 2015). 2016 yılında, öğrenciler ve öğretmenler, dizüstü bilgisayarlar, masaüstü bilgisayarlar, tabletler, cep telefonları gibi çeşitli farklı aygitlar kullanmaktadırlar. Bu süreç, okulların hangi makineleri satın alınacağına veya hangi çevrimiçi platformun benimseyeceğine karar vermesi olanağı sağlamıştır. Örneğin bazı öğretmenler Google sınıfını kullanabilecekken bazıları da Moodle veya Blackboard kullanabilmektedir (Hatch, 2017).

Singapur'da öğrenciler, İngilizce derslerinde etkileşimi sağlamak için, reklamlar gibi görsel metinleri analiz etmek için veya çevrimiçi bir açılama aracı teknolojiyi aktif olarak kullanmaktadır. Anadili derslerinde bir metni eș zamanlı olarak okuma ve akranlarıly bu metin veya metindeki görselleri tartışabilmektedir. Eğitim teknolojileri derslerinde ise yoğun bir şekilde kodlama, robotik ve 3D teknolojisi gibi deneysel etkinliklerde teknolojiden faydalanmaktadırlar (Zhao, 2017). Norveç eğitim sisteminde de bütün öğrencilerin eşit olarak ulaşabileceği teknolojik sınıf ortamları öğrencilerin kullanımına sunulmuştur. Okulların genel yapısı, birçok dersin/branşın kendine ait özel atölye ve dersliği bulunmaktadır. Bu dersliklerin ve atölyelerin araç-gereç ve teknoloji yönünden oldukça zengin oldukları belirtilmektedir. Öğrenciler temel eğitimden başlayarak ilerleyen sinıflara kadar birçok derste teknolojiyi kullanabilmektedir.

Çünkü ulusal öğretim programı hazırlanırken ders içerikleri teknolojik araçlarla da uyumlu olarak tasarlanmaktadır. 15-20 arası öğrenciden oluşan sınıflar da katıldıkları derslere göre her önceye bir bilgisayar düşmesinin yanı sıra bazı derslerde öğrencilerin tablet kullanmasına izin verilmektedir (Sahlberg, 2007). Uzay teknolojisindeki ilerlemeleri ve son zamanlarda yazılım alanında kendinden fazlaca söz ettiren Rusya'da, daha küçük yaştan itibaren sık1 bir teknoloji eğitimi verilmektedir. Ülke olarak bilim ve teknolojiye verilen büyük önem sonucunda, genellikle tıp, matematik, bilim ve uzay araştırmaları yüksek bir düzeydedir (Background Note: Russia. U.S. Department of State, 2016). 1 Ocak 2015'ten itibaren, 8 Aralık 2014 tarih ve 1559 tarihli Rusya Federasyonu Eğitim ve Bilim Bakanlığı'nın kararına göre, Rusya'daki tüm okul ders kitaplarının elektronik versiyonu zorunlu tutulmuştur (Ryan ve Rose, 2011, s. 265). Rusya Federasyonu Eğitim ve Bilim Bakanlığı'nın 2025 yılının sonuna kadar gerçekleştirmeyi planladığı öncelikli projelerle birlikte eğitimde birçok yenilik ve gelişim hedeflenmektedir. Öncelikli projelerin bazıları şunlardır:

“Rusya Federasyonu'nda Modern Dijital Eğitim Ortamı" Projesi: Projenin amac1, Rus dijital eğitim alanını geliştirerek tüm vatandaş kategorileri için sürekli eğitim firsatlarının sistematik kalite iyileştirmesi ve yaygınlaştırılması için 2018 koşullarını sağlamak ve 2025 yllının sonuna kadar 11 milyona kadar çevrimiçi kurslarda ustalaşan öğrenci sayısını artırmak.

“İleri teknolojiler için çalışanlar”: Projenin amac1, rekabetçi bir orta mesleki eğitim sistemi oluşturmak, yüksek nitelikli uzman ve işçilerin modern standartlara ve ileri teknolojilere göre eğitmek.

İnovasyon yaratma alanı olarak üniversiteler: Projenin amaç, 2018'de en az 5 ve 2025'te en az 10 önde gelen Rus üniversitesinde sürdürülebilir küresel rekabetçiliği sağlamak ve 2025'e kadar Rusya Fedarasyonu bölgelerinde teknolojik ve sosyal gelişim için 100 üniversite merkezi oluşturmak. 
Türkiye'de ise MEB tarafindan “Temel Eğitim Projesi”, "Intel Gelecek için Eğitim” ve FATİH Projesi” ile teknolojinin öğretim sürecinde etkin bir biçimde kullanılmasına yönelik çalışmalar yapılmıştır.

Eğitimde FATïH Projesi, eğitim ve öğretimde fırsat eşitliğini sağlamak ve okullarımızdaki teknolojiyi iyileştirmek amacıyla bilişim teknolojileri araçlarının öğrenme-öğretme sürecinde daha fazla duyu organına hitap edilecek şekilde, derslerde etkin kullanımı için başlatılmıştır. Bu prensiplerden yola çıkarak çözümü oluştururken başarı faktörleri 5 temel esasa dayandırılmıştır (MEB, 2016):

1. Erişilebilirlik: Her an her yerden, zaman ve araçlardan bağımsız olarak hizmet sunabilmek,

2. Verimlilik: Hedef odaklı, daha verimli çalş̧ma ortamlanı ve gelişim alanları sunabilmek,

3. Eşitlik (Fırsat Eşitliği): Tüm paydaşların en iyi hizmete erişilebilmesini sağlayabilmek,

4. Ölçülebilirlik: Gelişimin doğru değerlendirilebilmesi için sürecin ve sonuçların doğru ölçülebilmesini sağlamak, buna göre düzgün geri bildirim verebilmek,

5. Kalite: Tüm eğitimin kalitesini ölçülebilir şekilde yükseltmek.

Türkiye'de teknoloji entegrasyonuna yönelik en önemli çalşmalardan biri olan FATİH projesi kapsamında okullara etkileşimli tahta imkânı sağlanmıştır. Bununla birlikte proje kapsamında 2014 yilı sonuna kadar yaklaşık 730 bin tablet bilgisayar öğretmen ve öğrencilere dağttılmıştır. Milli Eğitim Bakanllğı (MEB) dağitılan tablet bilgisayarda kullanılmak amaciyla Eğitim Bilişim A $\breve{g} 1$ (EBA) sitesi üzerinden ekitap, ses, video, görsel öğeleri kullanıcılara sunmuştur (Kaysı ve Aydın, 2014, s. 72).

\section{İngiltere, Japonya, Norveç, Finlandiya, Singapur, Rusya ve Türkiye’de Ölçme Değerlendirme Uygulamalar1}

Ölçme ve değerlendire yapmak ülkelerin eğitim sistemlerindeki mevcut durumun anlaşılmasının yanında diğer ülkelerle karşılaştırmalar yaparak, geleceğe dönük eğitim politikaları geliştirmek açısından önemlidir. Bu yönde PISA sınavında başarı gösteren ülkelerdeki ölçme ve değerlendirme süreçlerine bakıldığında; İlkokul kademesinde Okullaşma oranı \%99 olduğu Japonya'da ölçme sistemi dersi içi etkinlikler ve katılımlara göre yapılan küçük quizlere göre yapılmaktadır (Türkoğlu, 1998). Zorunlu eğitimin 3 yll sürdüğü ortaokulda ise öğrenciler daha disiplinli ortamlarda eğitim alarak her dersten sinav olmaktadırlar (MEXT, 2018). Ortaokulu bitiren öğrenciler ise mart ayında yapılan liselere giriş sınavındaki performanslarına göre liselere yerleştirilmektedir. Japonya'da üniversiteye girişte öğrenciler arasında ciddi rekabet vardır. Öğrencilerin tamamı merkezi bir seçme sınavına girmek zorundadırlar. Üniversiteler kendileri ayrıca ikinci bir sınav yapmaktadırlar. Yerleştirme, genellikle, bu sınavın ortalaması alınarak yapılır (Günay ve Gür, 2009, s. 234).

Öğrenci performansı 4 kez ölçüldüğü İngiltere'de okul öncesi eğitim bitimi ile birlikte konuşma ve yazma, okuma ve dinleme, matematik ve fen konularında öğretmen değerlendirmesi ile resmi sınavlar yapılmaktadır. Daha sonra ise İngilizce ve matematik ulusal program sınavları ve ortaöğretim diploması almak için girilen GSCE - General CERTIFICATE of Secondary Education resmi sinav1 yapilmaktadır (DCSF, 2010; EURYBASE, 2010a).Zorunlu eğitimin ilköğretimin birinci ve ikinci kademesinden yedinci sınıfa kadar formel olarak herhangi bir sınav bulunmadığı Norveç’te İlköğretim üçüncü kademede sekiz ile onuncu sinıflarda sinavlar yapılarak notlar verilmektedir. Üçüncü kademede ise bütün derslerde senede en az 2 defa not vermeye yönelik sınav yapılmaktadır. En düşük not 1 ve en yüksek not 6 olarak belirlenmiştir. Üçüncü kademenin sonunda bütün öğrenciler ülke çapında bir sınava girer ve kademe boyunca yapılan bütün sınavların notlarını gösteren bir belge alırlar (European Commission, 2020). Değerlendirmede asıl amaç kontrol ya da denetim yapmak değil eğitimi geliştirmek ve öğrenme ortamlarını iyileştirmek olarak hedefleyen Finlandiya, öğrencilerin başarılarını ölçmede standart bir sistem kullanmamaktadır. Notlandırma öğrenciler arasında rekabete neden olabileceğinden Finli öğrenciler beşinci sınıfa kadar sayısal bir not almazlar Bu durum kanunla yasaklanmıştır. Öğrencilere sadece betimsel değerlendirmeler ve geribildirim verilir. Diğer bir deyişle ilkokul değerlendirmeden bağımsız bir alandır. Sadece temel eğitimde kriter temelli bir değerlendirme söz konusudur. Bunun yanında öğretmenler değerlendirmeyi öğrencilerin sınıf çalışmalarına, projelerine ve portfolyo dosyalarına göre yapmaktadır. Dolayısıyla Fin eğitim sisteminde hem süreç hem sonuç odaklı bir değerlendirme sistemi olduğunu söyleyebiliriz.

Singapur'da ise 6 yılllk ilkokul eğitiminden sonra öğrenciler İlkokul Bitirme Sınavına (Primary School Leaving Examination - PSLE) girerler (OECD, 2010; Chai, Tan, Deng ve Koh, 2016, s. 78; ESD, 2018). Ortaöğretime uygunluklarını değerlendiren PSLE'nin sonuçlarına göre, öğrenciler farklı ortaöğretim kurumlarına yerleştirilirler. Akademik yetenekliler için 'Express', ortalama yetenekli öğrenciler için 'Normal' 
veya akademik olarak en az eğimli olan öğrenciler 'Normal (Teknik)' ortaöğretim kademelerine devam ederler (Koh, 2018). Bu ortaöğretim kurumlarının öğrenim süresi 4 ile 5 yıl arasında değişmektedir (Low ve Tang, 2017). Rus eğitim sisteminde ise İlkokula başlayan öğrenciler, entelektüel seviyelerini ölçen teste girmektedirler. Genel ortaöğretimin sonunda, Ortak Devlet Sınavı (ЕГЭ) yapilmaktadır. Bu sinavda başarılı olan öğrencilere Orta Genel Eğitim Sertifikas1, Attestatob Sredem Obshchem Obrazovanii'ye verilir. Bunun ardından mezun olarak yükseköğretim kurumlarına başvurabilmektedirler (Çelik, 2015).

Türkiye de ise Milli Eğitim Bakanlığı tarafından 2017-2018 eğitim öğretim yöntemi ile başlanan LGS (Liseye Geçiş Sınavi) her yıl ilköğretimden ortaöğretime geçilirken merkezi bir sınav uygulanmaktadır. Bu sınavda öğrencilerin PISA ve TIMSS soruları esas alınarak beceri temelli mantık muhakeme yeteneğini ölçmek amaçlanmaktadır. Bu sınavla ortaöğretime yerel yerleştirme ve merkezi yerleştirme olmak üzere iki şekilde öğrenci alınmaktadır. Sınavı kazanan öğrenciler; Fen Lisesi, Anadolu Lisesi, Sosyal Bilimler Lisesi, Anadolu İmam Hatip Lisesi ve Mesleki ve Teknik Anadolu Lisesi türündeki liselerden tercihte bulunur. Sınavda belirli bir başarı eşiğine ulaşamayan öğrenciler ise adrese dayalı olarak okul tercihinde bulunabilir ve merkezi sınavla öğrenci almayan okullarda okumayı tercih edebilir. Sınava girmek zorunlu değildir. Yükseköğretime geçişte ise 2018 yllından itibaren YKS(Yükseköğretim Kurumları Sınavi) olarak adlandırlan merkezi bir sınav uygulanmaktadır. Bu sınav iki kademeli olarak; TYT(Temel Yeterlilik Testi) öğrencilerin sahip oldukları temel yeterliliklerini ölçen birinci oturum ve AYT(Alan Yeterlilik Testi) ögrencilerin kendi alanlarında sahip oldukları başarılarını ölçen ikinci oturum sınavı olarak uygulanmaktadır.

\section{PISA Başarısı}

Dünyadaki eğitim politikası ve sistemleri üzerinde büyük bir etkiye sahip olan Öğrenci Değerlendirme Programı (PISA), zorunlu eğitimin sonuna yakın 15 yaş grubu öğrencilere, üç yılda bir uygulanan ve öğrendikleri bilgileri gündelik yaşamda karşılaştıkları bir problem çözmede kullanma düzeyini ölçen bir sinavdır (Deng ve Gopinathan, 2016, s. 449). PISA değerlendirme de fen, okuma becerileri ve matematiğin temel konularına odaklanan PISA, üç boyutlu bir OECD çalışmasıdır (OECD, 2018). PISA sınav sonuçları ülkelerin eğitimdeki başarıları hakkında önemli veriler vermektedir. Bu yönde PISA sınavında başarı göstermiş ülkelere bakıldığında; Aşağıdaki tabloda Singapur, Japonya, Finlandiya, İngiltere, Norveç, Rusya ve Türkiye'nin PISA 2009, 2012, 2015 ve 2018 sinavlarına ilisskin konu alanlarına göre puanları ile OECD ortalamaları yer almaktadır (PISA, 2009; 2012; 2015; 2018).

PISA sınavlarına 2009 yılında katılan Singapur tüm alanlar dikkate alındığında alanında ortalama puanıyla en üst sıralarda yer alarak büyük bir başarı göstermektedir Aynı şekilde başarı sıralamasında en üst sıralarda olan Japonya'da Singapur gibi sınavlarında başarı sıralamasında yerini önemli oranda korumaya devam etmiştir. Eğitim konusunda başarılarını artıımak isteyen ülkelerin örnek aldığı Finlandiya PISA verilerine göre en başarılı ülkeler arasında yer almaktadır. Bununla birlikte 2009, 2012, 2015, 2018 yıllarındaki PISA sınavlarında istikrarlı bir şekilde başarı gösteren İngiltere, Norveç ve Rusya'nın OECD ortalamasının altına düşmediği görülmektedir (PISA, 2009; 2012; 2015; 2018; OECD, 2010b; 2014; 2016).

PISA sınavlarında Türkiye 2009, 2012, 2015 ve 2018 yıllarına bakıldığında OECD ortalamalarının altında bir başarı gösterdiği görülmektedir. Özellikle tüm alanlarda ortalama puanıyla en üst sıralarda yer alan Singapur'la oldukça büyük fark görünmektedir.

PISA sonuçları incelendiğinde Türkiye'nin 2009 dan 2018 e kadar puanlarında iki alanda artış gösterdiği ancak matematik okuryazarlığ alanında düşüş yaşadığı görülmektedir. Bu düşüşün matematik alanında 2015' e kadar devam ettiği ancak bakıldığında 2015 yllına göre 2018 yllında matematik okuryazarlığı alanında puanında artış olduğu görülmektedir. 2009 yılına göre kıyaslandığında ise matematik okuryazarlığı alanı dışında ülkemizin puanlarında artış olduğu ancak 2012 yılı ile kıyaslandığında fen ve matematik okuryazarllğı alanlarında puanlarda düşüş olduğu görünmektedir. 
Tablo 2. Singapur, Japonya, Finlandiya, İngiltere, Norvec, Rusya ve Türkiye'nin PIS A 2009-2012-2015-2018 Puan Siralamalar ile OECD ortalamalar

\begin{tabular}{|c|c|c|c|c|}
\hline & & $\begin{array}{c}\text { Fen Okuryazarliğı } \\
\text { Puan/Siralama }\end{array}$ & $\begin{array}{c}\text { Okuma Becerileri } \\
\text { Puan/Siralama }\end{array}$ & $\begin{array}{c}\text { Matematik Okuryazarlığı } \\
\text { Puan/Sıralama }\end{array}$ \\
\hline \multirow{8}{*}{ PISA 2009} & Singapur & 542 & 526 & 562 \\
\hline & Japonya & 538 & 520 & 529 \\
\hline & Finlandiya & 554 & 536 & 541 \\
\hline & İngiltere & 514 & 494 & 492 \\
\hline & Norveç & 500 & 503 & 498 \\
\hline & Rusya & 478 & 459 & 468 \\
\hline & Türkiye & 454 & 445 & 464 \\
\hline & $O E C D O r t$ & 501 & 493 & 496 \\
\hline \multirow{8}{*}{ PISA 2012} & Singapur & 551 & 542 & 573 \\
\hline & Japonya & 547 & 538 & 536 \\
\hline & Finlandiya & 545 & 524 & 519 \\
\hline & İngiltere & 514 & 499 & 494 \\
\hline & Norveç & 495 & 504 & 489 \\
\hline & Rusya & 486 & 475 & 482 \\
\hline & Türkiye & 475 & 448 & 463 \\
\hline & $O E C D O r t$ & 501 & 496 & 494 \\
\hline \multirow{8}{*}{ PISA 2015} & Singapur & 556 & 535 & 564 \\
\hline & Japonya & 538 & 516 & 532 \\
\hline & Finlandiya & 531 & 526 & 511 \\
\hline & İngiltere & 509 & 498 & 492 \\
\hline & Norveç & 498 & 513 & 502 \\
\hline & Rusya & 487 & 495 & 494 \\
\hline & Türkiye & 425 & 428 & 420 \\
\hline & $O E C D O r t$ & 493 & 493 & 490 \\
\hline \multirow{8}{*}{ PISA 2018} & Singapur & 551 & 549 & 569 \\
\hline & Japonya & 529 & 504 & 527 \\
\hline & Finlandiya & 522 & 520 & 507 \\
\hline & İngiltere & 505 & 504 & 502 \\
\hline & Norveç & 490 & 499 & 501 \\
\hline & Rusya & 478 & 479 & 488 \\
\hline & Türkiye & 468 & 466 & 454 \\
\hline & OECD Ort & 489 & 487 & 489 \\
\hline
\end{tabular}

\section{Tartışma, Sonuç ve Öneriler}

Uluslararası eğitim platformlarında yer edinmeyi hedefleyen ülkeler kendi kültürel, ekonomik ve politik verileriyle eğitim felsefelerini ve sistemlerini oluşturmayı başlangıç olarak görürler. Bu amaçla Türk eğitim sisteminde de bunu göz önünde bulundurarak programlarda farklılaşmalara gitmektedir. Sürecin en büyük tartışmasını ve yorumunu ise ilkokul programları kapsamaktadır. Türkiye de yaşanan bu program değişiklikleri birçok ülkede de görülmektedir. Özellikle 1980-1990'lı yıllar ABD, Avustralya, İngiltere, Hollanda, Çin, Rusya, Fransa, İspanya, Güney Afrika ve Malezya vb. gibi birçok ülkenin eğitim sistemlerinde reform hareketini başlattığ yıllar olmuştur. Eğitimde yaşanan bu değişikliklerinin asıl sebebi gelişen ve değişen yapıya uyum sağlayarak küresel anlamda da diğer ülkelerden geride kalmamak için insan kaynaklarını geliştirmeyi gerekli kılmışır (Bıkmaz, 2006, s. 99). Türkiye gelişmekte olan bir ülke olarak eğitim alanında özeleştiri yaparak sürekli radikal kararlar alarak eğitim felsefesinin temeline inmeden eğitim sistemi üzerinde değişikliler yapmaktadır.

Ancak istenilen başarı bu kararlara rağmen elde edilememektedir. Bu başarısızlıkta pek çok değişken neden olmaktadır. $\mathrm{Bu}$ nedenlerden en önemlisi ülkelerin programları oluştururken diğer ülkelerin programlarını birebir olarak uygulamasından kaynaklanmaktadır. Ülkeler programlarını geliştirirken gelişmiş ülkelerin programlarından kendi ülkelerinin sosyal, kültürel vs. yapılarını dikkate alarak uyarlamaları yapmaları beklenmektedir. Fakat ülkelerin farklı özellikleri analiz edilmeden aynen alınması halinde eğitim sisteminde ne kadar yapılırsa yapılsın başarıdan söz etmek güçleşir (Rogan ve Grayson, 2003, s. 1171).

Temelde öğrencilerin düşünceleri ve kavramsallaştırmaları üzerinde duran, birey merkezli eğitimi savunan ve evrensel nitelikteki bilimin savunulduğu yapılandırmacı yaklaşımı benimsemeyen toplumlarda toplumun gelişmişliğinden bahsetmek oldukça zordur. $\mathrm{Bu}$ da diğer ülkelerde yarış halinde olmaktan çok onların bir pazarı haline gelmelerine sebep olabilir (Aydın, 2012). Ayrıca gelişmiş ülkelerin aksine diğer ülkelerdeki eğitim değişikliklerinde konunun değişimin nasıl yapılacağına öncelik verilmesi gerekmektedir 
(Rogan ve Grayson, 2003, s. 1171). 2023 vizyon belgesinde yer alan günümüz dünyasında itibar edilen ana akım sistemlerinde hâkim bakış açısı, eğitimi işlevsel çıktılarıyla değerlendirmeye yatkındır. Bu bakış açısının bir sonucu olarak eğitimde birey sadece dönem şartlarına uygun olarak temel gereksinimleri karşılayacak şekilde sınırlandırılmaktadır. Oysaki birey sadece tek yönden ziyade bir bütün olarak düşünülüp, geleceğe yontulmaktan çok temelinde önce insan yetiştirmeyi hedef almalıdır.

PISA verilerine göre başarılı görülen ülkelerden Singapur, Finlandiya, İngiltere, Norveç, Japonya ve Rusya'nın eğitim sistemlerinin incelendiği bu bölümde eğitim sistemlerinde zorunlu eğitim genel olarak en az 9 yıldır. Bu zorunlu eğitim Singapur, Finlandiya Japonya'da 6 yaş iken İngiltere ve Norveç'te 5 yaşından başlamaktadır. Ancak zorunlu eğitim her ülkede ilkokuldan başlamamaktadır. İngiltere için okul öncesi dönem olarak kapsamakta; ancak en başarılı ülkeler olan Singapur, Finlandiya ve Japonya'da ilkokul adıyla başlamaktadır. İncelenen tüm ülkelerde insan hakları temel ilkelerinden olan eğitim hakkı göz önüne alınarak ücretsiz yürütülmektedir. Yine bu finansman eğitim yönetiminin merkezi ve yerelleşme durumuna göre değişse de genel olarak eğitimde yerellik ön planda tutulmuştur. Eğitim insanlık tarihi boyunca bilimden, felsefeden, sermayeden veya farklı değişkenlerden etkilenerek çeşitli değişimler göstermiştir. Dünyanın 1960'lı yıllara kadar modernizm, sonrasinda ise postmodernizm ideolojisinin etkisi altnnda kaldığı söylenmektedir. Bu ideolojiler ekonomik olarak gelişmiş ya da gelişmekte olan ülkeleri farklı yıllarda da olsa eğitimden sanata, mimariden psikolojiye kadar birçok alanda etkilemiştir. Batı ve Amerika toplumlarında 90'lı yllardan sonra, Türkiye'de ise 2004 yilından sonra tamamen etkisini gösteren post modern ideoloji ve bunun etkisiyle ortaya çıktığı ifade edilen yapılandırmacılık eğitim anlayışı eğitimin en merkezine oturmuştur (Koç, 2018, s. 49). Bu eğitim anlayışı gelecek nesillerin sahip olması istenilen bilgi ve becerilerden, bu bilgi ve becerilen nasıl kazandırılacağına yani öğretme-öğrenme ortamlarına kadar etkisini göstermektedir.

Neredeyse tüm dünyada hakim olan bu paradigma ile etkileşim içinde başat olarak ilerleyen bilim ve tabi ki dolayısıyla teknoloji hayatın her alanında olduğu gibi öğretme-öğrenme süreçlerinin de içinde olduğu söylenebilir. Gelecekte dünya veya Türkiye hangi ideoloji veya eğitim felsefesiyle eğitim süreçlerini planlayacağı çok öngörülemese bile, bu eğitim öğretim süreçlerinin teknolojiden tecrit edilemeyeceğini tahmin etmek zor olmayacaktır. Yaklaşık olarak son yirmi yıllık süreçte, PISA ve TIMMS gibi uluslararası sinavlarda üst sıralarda olan ülkelerin genel özelliklerinden birinin de teknolojinin eğitime entegresinde de başarılı olmalarıdır. Dolayısıyla eğitim-öğretim süreçlerinde teknolojinin yeri ve önemi fark edilmeli ve öğretimsel süreçlerin planlanmasında göz ardı edilmemelidir. Tabi ki teknolojiye fon ayırmak kadar, nitelikli ve içi dolu yatırımlar yapmaya dikkat etmek de önemlidir. Ülkemizde öğrencilerin değerlendirmeleri ilkokul 1, 2 ve 3. Sınıflarda öğrenci gelişim düzeyleri dikkate alınarak sınıf öğretmeni tarafindan çok iyi, iyi ve geliştirilmeli şeklinde değerlendirilirken; 4. Sınıfta sınavlar ve ders içi performanslarına göre puanla değerlendirilir. Ortaokullarda ise öğrencilerin başarıları, yazılı ve sözlü sinavlarda sürekli olarak değerlendirilmektedir. Yapılan bu değerlendirmeler; yarıyılda ve y1lsonunda, öğretim kademesine göre düzenlenen özel karnelerle işlenmektedir. Bir üst sınıfa yükselebilmek için, derslerde belirli bir başarı düzeyini göstermek gerekmektedir (Akalın, 2008). Bununla birlikte Türkiye'de ortaöğretim ve yükseköğretime geçişte ülke genelinde ulusal sinavlar yapılmaktadır. Ortaöğretime geçişte LGS (Liselere Geçiş Sınavı), yükseköğretime geçişte ise YKS (Yükseköğretim Kurumları Sınavı) uygulanmaktadır. Ülkemizdeki değerlendirme sistemine bakıldığında eğer hedeflenen verimli bir öğrenmeyi desteklemekse öğrencilerin hem süreçteki performansları hem de sonuç odaklı bir değerlendirmenin daha etkili olacağ1 düşünülmektedir.

Bununla birlikte dünyadaki eğitim politikası ve sistemleri üzerinde büyük bir etkiye sahip olan PISA sınav sonuçlarına bakıldığında Türkiye'nin istenilen seviyede olmadığını görmekteyiz. MEB, PISA'ya katılma amacını "Küreselleşen dünyada, eğitim alanında yapılan ulusal değerlendirme çalışmalarının yanı sıra, uluslararası düzeyde konumumuzu belirlemek amacıyla eğitim göstergelerine ihtiyaç duyulmaktadır. $\mathrm{Bu}$ nedenle belirli referans noktalarına göre Türkiye'nin eğitim alanında hangi düzeyde olduğunun, giderilmesi gereken eksikliklerin ve alınması gereken tedbirlerin belirlenmesi ve bu sayede de eğitim düzeyinin yükseltilmesi amacıyla bir OECD ülkesi olarak ülkemiz bu projeye katılmaktadır" ifadeleriyle açıklamaktadır (MEB, 2018). Bu bağlamda aşağıdaki tabloda da Türkiye'nin son üç sınavdaki PISA başarı oranlarını göstermektedir. 
Tablo 3. Türkiye'nin Son Dört PIS A'daki Bașar Oranlar (MEB, 2018)

\begin{tabular}{lcccccccc}
\hline DERSLER & 2009 & $\begin{array}{c}\text { OECD } \\
\text { Ortalamas }\end{array}$ & 2012 & $\begin{array}{c}\text { OECD } \\
\text { Ortalamas1 }\end{array}$ & 2015 & $\begin{array}{c}\text { OECD } \\
\text { Ortalamas1 }\end{array}$ & 2018 & $\begin{array}{c}\text { OECD } \\
\text { Ortalamas1 }\end{array}$ \\
\hline Fen Bilimleri & 454 & 501 & 475 & 501 & 425 & 493 & 468 & 489 \\
Matematik & 464 & 496 & 463 & 494 & 420 & 490 & 454 & 489 \\
Okuma & 445 & 493 & 448 & 496 & 428 & 493 & 466 & 487 \\
\hline
\end{tabular}

Tablo 2'de görüldüğü gibi Türkiye bu üç sınavda da her derste OECD ortalamasının altında görülmektedir. Bu durum birçok sebebi olabilir. Eğitime yapılan yatırım, öğretmen kalitesi, okullardaki donanım yetersizlikleri, sosyo-ekonomik sebepler gibi. Tabi ki bu tablo eğitimde yeni reformlar yapılamasını gerekli kılmaktadır. Bu bağlamada MEB'in 2023 Eğitim Vizyonu ümit verici görülmektedir. Bu araştırmada İngiltere, Japonya, Norveç, Finlandiya, Singapur ve Rusya eğitim sitemleri ile Türkiye eğitim sisteminin karşılaştırılması ile elde edilen sonuçlar 1şığında Türkiye'nin daha başarılı olabilmesi için şu önerilerde bulunulabilir: Birçok gelişmenin ve yeniliklerin yaşandığı bu çağda Türk Eğitim Sistemi’nin kendisinden beklenen sıçramayı gerçekleştirebilmesi için başarılı ülkelerin eğitim sistemlerinin incelenerek Türkiye'nin gelecekteki eğitim reformları bu sonuçlara göre şekillendirilebilir. Öğretim programları çağın gereksinimlerine, öğrenci ve okulların ihtiyaçlarına göre şekillendirilebilecek esneklikte hazırlanabilir.

\section{Etik Beyan}

"İngiltere, Japonya, Norveş, Finlandiya, Singapur, Rusya ve Türk Ë̆̈tim Sistemlerinin Karşılaştırmal Olarak Incelenmesi" başlıklı çalışmanın yazım sürecinde bilimsel kurallara, etik ve alıntı kurallarına uyulmuş; toplanan veriler üzerinde herhangi bir tahrifat yapilmamış ve bu çalışma herhangi başka bir akademik yayın ortamına değerlendirme için gönderilmemiştir. Bu araştırma doküman incelemesine dayalı olarak yapıldığından etik kurul kararı zorunluluğu bulunmamaktadır.

\section{Kaynakça}

Aldemir, A. Y (2010). Türkiye Ve Japonya'da İngiliz̨e ögretmeni yetiştirme sistemlerinin karşılaştırlması (Yüksek Lisans Tezi). Balıkesir Üniversitesi, Sosyal Bilimler Enstitüsü, Balıkesir.

Aoki, M. (2017) Let's discuss changes to education in Japan. Erişim adresi: https://www.japantimes.co.jp/life/2017/03/06/language/lets-discuss-changes-education japan/\#.XK0CXpgzZ3j

Ataünal, A. (2003). Niçin ve nasıl bir ögretmen? Ankara: Mev Ar-Ge Merkezi.

Avc1, B. ve Toy, B. Y. (2018). Norveç ve Türkiye eğitim sistemleri ile öğretmen yetiştirme sistemlerinin karşılaştırılması. Akedeniz. Ë̆itim Arasțtrmalar Dergisi, 12(25), 39-59.

Aydın, H. (2012). Yapilandirmachllk felsefi temeller usığgnda. Ankara: Nobel Yayınları

Background Note: Russia. U.S. Department of State. Erişim adresi: https://www.wikizeroo.net/?q=aHR0cDovL3dlYi5hcmNoaXZILm9yZy93ZWIvMjAxNjA2MTUxMjAzNTU vaHR0cDovL3d3dy5zdGF0ZS5nb3Yvci9wYS9laS9iZ24vMzE4My5odG0

Bakioğlu, A. ve Göçmen. G. (2013). Singapur eğitim sistemi. Ayşen Bakioğlu (Ed.), Karşslasstrrmalu eğitim yönetimi (ss. 127-155). Ankara: Nobel Akademik Yayincllk.

Bıkmaz, F. (2006). Yeni ilköğretim programlar1 ve öğretmenler. Ankara Üniversitesi Eğitim Bilimleri Fakültesi Dergisi, $39(1), 99-116$.

Blaster, M. (2016). Japan's first drone high school course to begin next year, teaches piloting, law and more. Erişim adresi: https://soranews24.com/2016/08/05/japans-first-drone-high-school-course-to-begin-next-yearteaches-piloting-law-and-more/

Boavista, C. (2017). Norway: Its educational system. Journal of Education and Human Development, 6(2), 113-116.

Chai, C. S., Tan, L. Deng, F. ve Koh, J. H. L. (2016). Examining pre-service teachers design capacities for web-based 21 st century new culture of learning. Australasian Journal of Educational Technology, 33(2), 78-95.

Çayır, D.(2015). Eğitim Felsefeleri Nedir? Erişim adresi: https://indigodergisi.com/2015/04/egitim-felsefeleri/

Çelik, N. (2015). Türkiye ve Rusya Federasyonu ortä̈ğretim Ingiližce dersi ögretim programlarmmn kearşlasstırlması (Yüksek Lisans Tezi). Gaziosmanpaşa Üniversitesi. Eğitim Bilimleri Enstitüsü, Tokat.

Çınar, A. (2007) Modern batı dïşüncesi ekseninde rasyonel teoloji. İstanbul: Düşünce Kitabevi

Demirel, Ö. (2000). Karşslaştırmali eğitim. Ankara: PegemA Yayıncılık.

Demirel, Ö. (2012). Eğitim sö̈lliğ̈ï (5. Baskı). Ankara: Pegem Akademi Yayınc1lk.

Deng, Z. ve Gopinathan, S. (2016). PISA and high-performing education systems: Explaining Singapore's educationsuccess. ComparativeEducation, 52(4), 449-472. doi:10.1080/03050068.2016.1219535

Department for Children, Schools andFamilies. (2010). Guide tothelawforschoolgovernors. Erişim adresi: https://assets.publishing.service.gov.uk/government/uploads/system/uploads/attachment_data/file/340594/ DCSF-Accounts_2009-10.pdf 12.07.2021

DET (2011). The education mirror 2011. Oslo: Utdanningsdirektoratet. 
Education in Finland (2017). Finnish education in a nutshell.
https://www.oph.fi/download/146428_Finnish_Education_in_a_Nutshell.pdf
Education
https://assets.publishing.service.gov.uk/government/uploads/system/uploads/attachment_data/file/219167/
v01-2012ukes.pdf
Erdoğan, İ. (2003). Karşılaştırmalı eğitim: Türk eğitim bilimleri çalışmaları içinde önemsenmesi gereken bir alan. Türk Eğitim Bilimleri Dergisi, 1(3), 265-282.

Ertürk, R. (2012). Varolusssal Din Felsefesine Giriş. İstanbul:Yarın Yayınları.

ESD (2018). EducationStatistics Digest. Erişim adresi: https://www.moe.gov.sg/docs/defaultsource/document/publications/education-statistics-digest/esd_2018.pdf

European Commission (2020). How is the commission working to deliver a European education arena? Erişim adresi: https://ec.europa.eu/education/study-in-europa/country-profiles/norwey

EURYBASE (2010a). Organisation of theeducationsystem in the United Kingdom-England, WalesandNorthernIreland. Erişim adresi:

https://www.exeter.ac.uk/media/universityofexeter/collegeofsocialsciencesandinternationalstudies/education/ pgce/pre-coursedocuments/pre-coursedocuments2017-18/Secondary_MFL_-

_Eurydice_explanation_of_the_English_education_system.pdf

Eurydice (2006). The education system in England, $W$ ales and Northern Ireland2006. European Comission: Eurydice

Eurydice (2007). Eurybase The Information Database on Education Systems in Europe. Erişim adresi: https://ctne.fct.unl.pt/pluginfile.php/1282/mod_folder/content/0/uk_educational_system.pdf?forcedownloa $\mathrm{d}=1$

Eurydice (2011). Türk Eğitim Sisteminin Örgütlenmesi Ankara: MEB Basımevi. Erişim adresi: http://sgb.meb.gov.tr/eurydice/kitaplar/Turk_Egitim_sistemi_2011/Turk_Egitim_Sisteminin_Orgutlenmesi_ 2011.pdf

Eurydice (2018). United Kingdom - England Overview. Erişim adresi: https://eacea.ec.europa.eu/nationalpolicies/Eurydice /content/united-kingdom-england_en

Eurydice (2018a). Norway Overview Erişim adresi: https://eacea.ec.europa.eu/national-policies/Eurydice /content/norway_en

Gutek, G. L. (2017). Eğitime felsefi ve ideolojik yaklaşımlar. N. Kale (Ed.). Philosophical and Ideological Perspectives on Education. Ankara: Ütopya Eğitim Dizisi.

Günay, D. ve Gür, B. S. (2009). Dünyada üniversiteye giriş sistemleri ve ÖSS. İ. Bircan (Ed.) Türkiye'nin 2023 vizyonunda üniversiteye giris sistemi kongresi (s. 234-243). Ankara: Atılım Üniversitesi.

Hatch, T. (2017). A new model forintegratingtechnology in schools? Thework of eduLab in Singapore.

İpek, C. (2001). Japonya'da yerel yönetimler ve eğitim. Cumburiyet Üniversitesi İktisadi ve İdari Bilimler Dergisi, 2(2), 175 187.

Jackson, R. (2004). Intercultural educationan drecent European pedagogies of religious education. Intercultural education, 15(1), 3-14.

Just Landed (2019). Schools in Norway, The Norwegian Education System. Erişim adresi: https://www.justlanded.com/english/Norway/Norway-Guide/Education/Schools-in-Norway

Kaysı, A. G. F. ve Aydın, H. (2014). Fatih projesi kapsamında tablet bilgisayar içeriklerinin değerlendirilmesi. EInternational Journal of Educational Research, 5(3), 72-85.

Koç, M. H. (2018). Etkinlik Çalışmaları Değerlendirme Ölçeği: Bir Ölçek Geliştirme Çalışması. JASS Dergisi, 67, 4959

Koh, H. H. (2018). The leadership role of middle leaders in six selected primary schools in Singapore (Doctoral Dissertation). Erişim adresi: http://hdl.handle.net/11343/213895

Lai, H. J. (2010). Secondary school teacher's perceptions of interactive White board training workshops: A case study fromTaiwan. Educational Technology, 26(4), 511-522.

Legco, (2019). Erişim adresi: www.legco.gov.h

Leino, K. (2014). The Relationship between ICT use and reading literacy Focus an 15-year-old Finnish students in PIS A Studies. Finnish Institute For Educational Research, University of Jyvaskyla.

Levent, F. ve Yazıcı, E. (2014). Singapur eğitim sisteminin başarısına etki eden faktörlerin incelenmesi. Eğitim Bilimleri Dergisi, 39, 121-143.

Lim, K. (2013). Teacher Education in Singapore. doi: 10.13140/2.1.3100.2245.

Low, L. E. ve Tang, S. O. (2017). Teacher education policy: Recruitment, preparation and progression. Erişim adresi: https://www.springer.com/cda/content/document/cda_downloaddocument/9789811033841c2.pdf?SGWID=0-0-45-1600822-p180490251

Malaty, G. (2006). What are the Reasons Behind the Success of Finland in PISA? Gazette des Mathematiciens, 108, 5966.

McMillan, J. H. (2000). Educational research: Fundamentals for the consumer (3rd Edition). New York: Longman.

MEB (2016). Milli Eğitim İstatistikleri örgün eğitim 2015/’16. Erişim adresi: http://sgb.meb.gov.tr/meb_iys_dosyalar/2016_03/18024009_meb_istatistikleri_orgun egitim_2015_2016.pdf

MEB (2016). fatihprojesi.meb.gov.tr. Erişim adresi: http:// fatihprojesi.meb.gov.tr/proje-hakkinda/ 
MEB (2017). PIS A 2015 ulusal raporu. Ankara: MEB Yayını.

MEB (2018). Erişim adresi: http://pisa.meb.gov.tr/wp-content/uploads/2014/11/PISA2015_UlusalRapor.pdf adresinden 31.12.2018

MEB (2021). Türkiye'de Dönemlere Göre Net Okullaşma Oranı. Erişim adresi: http://sgb.meb.gov.tr/meb_iys_dosyalar/2020_09/04144812_meb_istatistikleri_orgun_egitim_2019_2020.pdf

MEC (2017). Finnish in aducation a https://www.oph.fi/download/146428_Finnish_Education_in_a_Nutshell.pdf adresinden erişildi.

MEXT [Japon Eğitim, Kültür, Spor, Bilim ve Teknoloji Bakanlığ1]. (2018). Outline of HigherEducation. Erişim adresi: http://www.mext.go.jp/english/

Ministry of Education and Culture [MEC] (2017). Education System in Finland. Erişim adresi: http://www.minedu.fi/OPM/Koulutus/koulutusjaerjestelmae/?lange

MOE (2015). Ministry of Education. Bringingoutthebest in everychild. Erişim adresi: https://www.moe.gov.sg/docs/default-source/document/about/files/moe-corporate-brochur e.pdf

MOE (2018a). Ministry of Education. Erişim adresi: https://www.moe.gov.sg/education/education-system

MOE (2018b). Ministry of Education. Bringing out the best in every child. Erişim adresi: https://www.moe.gov.sg/docs/default-source/document/about/files/moe-corporate-brochur e.pdf

Nazarova V.N. (2014). Education in Russia. Moscow: Pero.

NCEE (2019). Building a Better System the NCEE Blueprint. Erişim adresi: www.ncee.org

NFER (2019). Educational Research Journal. Erişim adresi: www.nfer.ac.uk

Nuffic (2015). Education system Japan described and compared with the Dutch system,

OECD (2010). PISA 2009 Results: What students know and can do - Student performance in reading, mathematics and science (Volume I). doi: 10.1787/9789264091450.

OECD (2010). Singapore: Rapid Improvement Followed by Strong Performance. Erişim adresi: https://www.oecd.org/countries/singapore/46581101.pdf

OECD (2010b). PISA 2009 at a Glance. OECD Publishing. doi:10.1787/9789264095298-en

OECD (2013). Education Policy Outlook: Norway Erişim adresi: https://www.regjeringen.no/globalassets/upload/kd/vedlegg/internasjonalt/unesco/nor_profile_final_versio n_en.pdf

OECD (2014). PISA 2012 Results: WhatStudentsKnowand Can Do - StudentPerformance in Mathematics, Reading.OECD Publishing.doi:10.1787/9789264201118-en

OECD (2015). Education Policy Outlook Japan. Erişim adresi: https://www.oecd.org/education/Japan-countryprofile.pdf

OECD (2015). Results From PISA 2015. Erişim adresi: https://www.oecd.org/pisa/PISA-2105-Financial-LiteracyRussian-Federation.pdf

OECD (2018). Global forum on Transparencyand Exchange of Information forTaxPurposes: Singapore 2018 (Second Round): Peer Review Report on the Exchange of Information on Request, OECD Publishing, Paris. Erişim adresi: https://read.oecd-ilibrary.org/taxation/global-forum-on-transparency-and-exchange-ofinformation-for-tax-purposes-singapore-2018-second-round_9789264306165-en\#page4

Phillips, D. C. ve Soltis, J. F. (2004). Perspectives on learning. New York: Teachers College Press.

Regjeringen (2020). Karaktersnittet fortsetter. Erişim adresi: https://www.regjeringen.no

Research report: UK (2017). Erişim adresi: https://www.gov.uk/government/collections/research-reports

Rogan, J. M. ve Grayson, D. J. (2003). Towards a theory of curriculum implementation with particular reference to science education in developing countries. International Journal of Science Education, 25 (10), 1171-1204.

Ryan, M. ve Rose, S. (2011). Number of Instructional Days/ Hours in the School Year. Education Commission of the States, 15(12), 265-297. Erişim adresi: http://www.ecs.org/clearinghouse/95/05/9505.pdf

Sahlberg, P. (2007). Lessons from Finland. American Educator. Erişim adresi: http://www.cimo.fi/instancedata/prime_product_julkaisu/cimo/embeds/cimo.www.structure/25535_Americ an_educator_summer_2011.pdf

Şimşek, M., Tuncer, M. ve Dikmen, M. (2018). PISA 2015’e katılan öğrencilerin PISA'ya ilişkin görüşleri. Uluslararası Sosyal Arasttrmalar Dergisi, 11(58), 559-569.

Tutkun, Ö. F. (2010). 21. yüzyılda eğitim programının felsefi boyutları. Gaž Üniversitesi, Gaz̧i Eğitim Fakültesi Dergisi, 30(3), 993-1016.

Türkoğlu, A. (1998). Karşılaștırmalı eğitim dünya ülkelerinden örneklerle. Adana: Baki Kitabevi.

UNECOPES (2001). Quality Assurance in Higher Education in the Russian Federation. Erişim adresi: https://www.qqi.ie/QualRec\%20Country\%20Education\%20Profiles/Russia\%20Education\%20System.pdf

Volkava, T. (2017). Russian Federation ECEC Workforce Profile. Erişim adresi: http://www.seepro.eu/English/pdfs/RUSSIA_ECEC_Workforce..pdf

Wells, H. K. (2003). Emperyalizmin felsefesi pragmatizm.(2. Bask1). İstanbul:Sorun yayınlar1.

Yıldırım, A. ve Şimşek, H. (2006). Sosyal bilimlerde nitel araştırma yöntemleri (6. baskı). Ankara: Seçkin Yayıncılık.

Zhao, I (2017). Singapore: World Class Education Embracesed Techand Skills Based Learning. Erişim adresi: https://www.emergingedtech.com/2017/02/singapore-world-class-education-embraces-edtech-and-skillsbased-learning/ 


\section{EXTENDED ABSTRACT}

Education systems are shaped according to the human profile that countries want to raise. In this context, countries are structuring their educational visions and educational practices within the scope of this vision according to the characteristics they want qualified individuals to be trained in the future. Comparative education is expressed as a science that is applied in various societies, countries, regions and historical periods, by comparing the education systems sometimes as a whole and sometimes in several aspects, determining the common and beneficial aspects and trying to benefit from this in education, theory and practice, education policy, educational planning and innovation studies (Demirel, 2012).

Our country also participates in the PISA exam as an OECD country. However, according to the exam results, it is in the lower ranks among the countries in general. This situation reveals the necessity of examining different aspects of our country's education system from the education systems of countries that are successful in PISA. Erdoğan (2003, p. 265) stated that the innovations to be made by making use of the experiences of other countries in the Turkish education system will contribute to being more controlled and based. In this direction, it can be said that examining the education systems of successful countries is an important step for Turkey's future education reforms. In this study, the education systems of England, Japan, Norway, Finland, Singapore and Russia, which are among the most developed countries and successful in international exams such as TIMMS and PISA, and the education system of Turkey. This study is aimed to examine comparatively the philosophy of education, the general structure of the education system, learning-teaching environments, assessment and evaluation practices in education and teacher training systems. The existing education systems of the relevant countries were examined in the study and the general data that could be reached were compared in various dimensions, and similarities and differences were revealed.

The research was carried out in accordance with the holistic multiple case study design, one of the qualitative research designs. The reason for choosing the holistic multiple case study design among the qualitative research designs in this research is to examine the existing education systems of the relevant countries (England, Japan, Norway, Finland, Singapore, Russia and Turkey) according to the determined criteria and then compare these situations in line with the research problem.

Civilization is experiencing a rapid change depending on the developments. Changes in technology and science are examples of this. Depending on these developments, countries aim to become an information society by considering the needs of the age, giving importance to the development of individuals in terms of education. Not following the developments means not being able to take your place in the international community, not being able to compete and becoming dependent (Ataünal, 2003). There are many innovations and developments that the 21 st century has brought to societies. Education is needed to bring these to people. Education is a system that consists of many elements. Such a system definitely has a philosophy (Tutkun, 2010, p. 993). Education, in a very general sense, includes all social processes that prepare people for cultural life, and it is held in schools, which are social institutions where people are educated in terms of values, abilities and knowledge in the official and intellectual sense (Gutek, 2017). In this case, in order for a curriculum to be effective, it must have an educational philosophy and teaching approach that accurately reveals its objectives. The philosophy of education is the question of "How should we raise an individual?" is the answer to the question.

Singapore, which participated in the PISA exams in 2009, shows a great success by being at the top with its average score in its field when all fields are taken into account. Finland, which is taken as an example by countries that want to increase their success in education, is among the most successful countries according to PISA data. However, it is seen that England, Norway and Russia, which consistently succeeded in the PISA exams in 2009, 2012, 2015 and 2018, did not fall below the OECD average (PISA, 2009; 2012; 2015; 2018; OECD, 2010b; OECD, 2014; 2016). Looking at the years of 2009, 2012, 2015 and 2018 in Turkey in PISA exams, it is seen that the performance is below the OECD average. Especially with Singapore, which ranks at the top with its average score in all fields, there seems to be a huge difference.

According to the PISA 2018 results, Turkey's average score in reading skills increased by 38 points compared to 2015 and reached 466, and the average mathematical literacy score increased by 34 points to 454. Similarly, the average score in the field of science literacy increased to 468 , with an increase of 43 points compared to 2015. Therefore, it is seen that the scores of our country increased compared to 2015 
in all three areas investigated, and the greatest improvement compared to the previous period was achieved in science literacy. When compared to 2009, it is seen that there is an increase in the scores of our country except for the field of mathematical literacy, but when compared to 2012, there is a decrease in the scores in the fields of science and mathematics literacy.

In this study, in the light of the results obtained by comparing the education systems of England, Japan, Norway, Finland, Singapore and Russia with the education system of Turkey, the following suggestions can be made for Turkey to be more successful: there is a rapid development and change in scientific, technological, economic and social fields. Today, Turkey's future education reforms can be shaped according to these results by examining the education systems of successful countries in order for the Turkish Education System to achieve the expected leap. Curriculums can be prepared with the flexibility to be shaped according to the needs of the age and the needs of students and schools. 